\title{
ipen
}

INSTITUTO DE PESQUISAS ENERGÉTICAS E NUCLEARES Autarquia associada à Universidade de São Paulo

EFEITOS DA RADIAÇÃO GAMA NO CRESCIMENTO DE ASPERGILLUS FLAVUS PRODUTOR DE AFLATOXINAS E NO EMPREGO DA TÉCNICA DA REAÇÃO EM CADEIA DA POLIMERASE (PCR) EM AMOSTRAS DE GRÃOS DE MILHO INOCULADAS ARTIFICIALMENTE.

\section{SIMONE AQUINO}

Dissertação apresentada como parte dos requisitos para obtenção do Grau de Mestre em Ciências na Área de Tecnologia Nuclear - Aplicações

Orientadora:

Dra. Anna L. C. H. Villavicencio

SÃO PAULO

2003 


\title{
INSTITUTO DE PESQUISAS ENERGÉTICAS E NUCLEARES
} Autarquia associada à Universidade de São Paulo

\author{
EFEITOS DA RADIAÇÃO GAMA NO CRESCIMENTO DE \\ ASPERGILLUS FLAVUS PRODUTOR DE AFLATOXINAS E NO \\ EMPREGO DA TÉCNICA DA REAÇÃO EM CADEIA DA POLIMERASE \\ (PCR) EM AMOSTRAS DE GRÃOS DE MILHO INOCULADAS \\ ARTIFICIALMENTE.
}

\section{SIMONE AQUINO}

Dissertação apresentada como parte dos requisitos para obtenção do Grau de Mestre em Ciências na Área de Tecnologia Nuclear Aplicações

Orientadora:

Dra. Anna L. C. H. Villavicencio 


\title{
EFEITOS DA RADIAÇÃO GAMA NO CRESCIMENTO DE ASPERGILLUS FLAVUS PRODUTOR DE AFLATTOXINAS E NO EMPREGO DA TÉCNICA DA REAÇÃO EM CADEIA DA POLIMERASE (PCR) EM AMOSTRAS DE GRÃOS DE MILHO INOCULADAS ARTIFICIALMENTE.
}

\author{
Simone Aquino
}

\section{RESUMO}

O presente trabalho teve como objetivos verificar os efeitos da radiação gama em grãos de milho contaminados artificialmente com Aspergillus flavus Link produtor de aflatoxinas; demonstrar a aplicação da técnica da Reação em Cadeia da Polimerase (PCR) no diagnóstico de A. flavus, bem como verificar o efeito da radiação no perfil das bandas de DNA. Vinte amostras de grãos de milho com $200 \mathrm{~g}$ cada foram irradiadas individualmente com $20 \mathrm{kGy}$, para eliminar a contaminação microbiana. Em seguida, as amostras foram inoculadas com A. flavus toxigênico ( 1 x $10^{6}$ esporos $/ \mathrm{ml}$ ), incubadas por 15 dias a $25^{\circ} \mathrm{C}$ em ambiente com umidade relativa ao redor de 97,5\% e irradiadas com 0;2; 5 e 10 kGy. As amostras, 5 para cada dose de irradiação, foram analisadas individualmente quanto ao número de células fúngicas, atividade de água, teste de viabilidade (diacetato de fluoresceína e brometo de etídio), PCR e detecção de aflatoxinas (AFB). Os resultados demonstraram que as doses utilizadas foram efetivas na redução do número de Unidades Formadoras de Colônias (UFC/g), principalmente as doses de 5 e 10 kGy. Em adição, o teste de viabilidade mostrou uma diminuição de células viáveis com o aumento das doses de irradiação. A redução de $\mathrm{AFB}_{1}$ e $\mathrm{AFB}_{2}$ foi mais eficiente com o emprego de 2 kGy, comparativamente à dose de $5 \mathrm{kGy}$, enquanto a dose de $10 \mathrm{kGy}$ degradou totalmente as aflatoxinas. Além disso, observou-se que $\mathrm{AFB}_{2}$ apresentou-se mais radiosensível. O emprego da técnica de PCR revelou a presença de bandas de DNA em todas as amostras. 


\title{
EFFECT OF GAMMA RADIATION ON THE GROWTH OF ASPERGILLUS FLAVUS AFLATOXINS PRODUCER AND ON THE USE OF POLYMERASE CHAIN REACTION TECHNIQUE (PCR) IN SAMPLES OF MAIZE GRAINS ARTFICIALLY INOCULATED
}

\section{Simone Aquino}

\begin{abstract}
The aim of this present study was to verify the effects of gamma radiation on the growth of Aspergillus flavus Link aflatoxins producer; to demonstrate the application of Polymerase Chain Reaction (PCR) technique in the diagnostic of A. Flavus, as well to verify the effect of radiation in the profile of DNA bands. Twenty samples of grains maize with $200 \mathrm{~g}$ each were individually irradiated with $20 \mathrm{kGy}$, to eliminate the microbial contamination. In following, the samples were inoculated with an toxigenic A. flavus ( $1 \times 10^{6}$ spores $\left./ \mathrm{ml}\right)$, incubated for 15 days at $25^{\circ} \mathrm{C}$ with a relative humidity of around $97,5 \%$ and irradiated with $0 ; 2 ; 5$ and $10 \mathrm{kGy}$. The samples, 5 to each dose of irradiation, were individually analyzed for the number of fungal cells, water activity, viability test (fluorescein diacetate and ethidium bromide), PCR and aflatoxins (AFB) detection. The results showed that the doses used were effectives in reducing the number of Colony Forming Units (CFU/g) mainly the doses of 5 and $10 \mathrm{kGy}$. In addition, the viability test showed a decrease of viable cells with increase of irradiation doses. The reduction of $\mathrm{AFB}_{1}$ and $\mathrm{AFB}_{2}$, was more efficient with the use of $2 \mathrm{kGy}$ in comparison with the dose of $5 \mathrm{kGy}$, while the dose of $10 \mathrm{kGy}$, degraded the aflatoxins. Thereby, it was observed that $\mathrm{AFB}_{2}$ showed to be more radiosensitive. The use of PCR technique showed the presence of DNA bands, in all samples
\end{abstract}




\section{1- INTRODUÇÃO}

\section{1- Considerações gerais}

Os fungos podem causar uma série de danos aos grãos durante o plantio e colheita, bem como durante o armazenamento (Silliker \& Elliott, 1980). Os efeitos da invasão fúngica incluem a diminuição do poder de germinação, emboloramento visível, descoloração, odor desagradável, perda de matéria seca, aquecimento, cozimento, mudanças químicas e nutricionais, perda da qualidade e produção de micotoxinas (Christensen \& Kaufman, 1969). Vários gêneros fúngicos podem produzir micotoxinas, entretanto, as toxinas mais importantes são freqüentemente produzidas pelos gêneros Aspergillus, Penicillium e Fusarium (Almeida, 1996).

Aflatoxinas são metabólitos secundários produzidos por espécies do gênero Aspergillus, principalmente A. flavus, A parasiticus e A. nomius. São compostos altamente tóxicos, mutagênicos, teratogênicos e carcinogênicos encontrados em uma ampla variedade de produtos agrícolas importantes tais como amendoim, milho, arroz e caroço de algodão. Aflatoxinas são encontradas em muitos países, especialmente em regiões tropicais e subtropicais onde condições de temperatura e umidade são ótimas para o crescimento dos fungos e produção da toxina (Rustom,1997). Sabe-se que a produção de aflatoxinas por cepas de A. flavus ocorre devido à secagem e armazenagem inadequadas do produto. No caso do milho, teores de umidade acima de $17,5 \%$ e temperaturas superiores a $13^{\circ} \mathrm{C}$, favorecem a formação da toxina (Rehana \& Basappa, 1990).

Em nosso país, durante a maior parte do ano, prevalecem condições de clima úmido e quente que propiciam o desenvolvimento fúngico e a produção de micotoxinas. O período da safra, muitas vezes, coincide com épocas chuvosas do ano, o que dificulta ou mesmo impede a 
secagem natural do produto logo após a colheita até os níveis considerados seguros para a estocagem. A infra-estrutura para secagem artificial do produto é freqüentemente inexistente ou aquém da necessária. Nessas situações, os grãos permanecem temporariamente armazenados sob condições críticas, que favorecem o desenvolvimento de fungos e a contaminação do produto por micotoxinas, tornando-o impróprio para o consumo humano ou animal (Castro, 2003).

Os métodos convencionais para detecção de fungos em alimentos incluem cultivo e identificação taxonômica, de acordo com a morfologia das culturas, porém tais métodos consomem muito tempo. A técnica de PCR (Reação em Cadeia da Polimerase) é freqüentemente empregada para a detecção de microrganismos patogênicos ou toxigênicos em vários substratos, incluindo alimentos (Fach et al.,1995). Métodos rápidos para a identificação de cepas de fungos aflatoxinogênicos em produtos alimentícios estariam disponíveis para garantir a segurança toxicológica dos alimentos (Geisen, 1996).

As radiações ionizantes produzem mudanças químicas que podem matar ou inativar microrganismos. Muitas aplicações são realizadas com o intuito de apenas causar redução dos microrganismos presentes em número e variedade, e, conseqüentemente, eliminar o risco de incidência de doenças veiculadas por alimentos (WHO, 1994). A irradiação elimina contaminantes microbianos por inativação parcial ou total do material genético dos microrganismos ou parasitas contaminantes dos alimentos. O efeito mais importante é a interação de radiação com as moléculas de água através da produção de radicais e íons que atacam o DNA dos microrganismos (Farkas, 1985).

A radiosensibilidade de microrganismos pode ser influenciada por vários fatores, tais como: temperatura do ambiente, atmosfera, $\mathrm{pH}$, umidade do substrato e umidade relativa do ar 
(Hilmy et al., 1995; Saleh \& Aziz, 1996; Abd El-Aal \& Aziz, 1997), analisando a sensibilidade de fungos à radiação gama, registraram que a dose necessária para a completa inibição do fungo em diferentes alimentos e produtos alimentícios, variou de 4 a $6 \mathrm{kGy}$. Várias publicações sugerem que os fungos são muito sensíveis à radiação gama. Neste sentido, Refai et al., $1996 \mathrm{e}$ Youssef et al., 1999, constataram diminuição no crescimento fúngico e na produção de micotoxinas após a irradiação de alimentos. 


\section{2-OBJETIVOS}

Com base nas considerações gerais citadas, o trabalho teve como objetivos:

- Verificar os efeitos da radiação ionizante no fungo Aspergillus flavus, produtor de aflatoxinas, em grãos de milho contaminados artificialmente;

- Demonstrar a aplicação da técnica da Reação em Cadeia da Polimerase (PCR) no diagnóstico de A. flavus presente em grãos de milho;

- Verificar a influência do efeito da radiação gama no perfil das bandas de DNA. 


\section{3-REVISÃO DA LITERATURA}

\section{1 - O Milho}

O milho, cientificamente designado Zea mays L., é uma planta alta, robusta, monocotiledônea, pertencente à família das gramíneas, largamente utilizada como fonte de alimento em vários países. Na constituição do milho há, em média, 60 \% de carboidratos, $10 \%$ de proteínas, 4 \% de lipídeos, além de minerais e vitaminas (Fancelli, 1983). Constitui um dos mais importantes grãos cultivados no mundo, sendo esse o cereal de maior produção no Brasil (35 milhões de toneladas nas safras de 2001/2002). A produção brasileira desse grão só é superada pela dos Estados Unidos e China (CONAB, 2002).

Portanto, torna-se de extrema importância o desenvolvimento de técnicas que controlem e evitem a produção de aflatoxinas durante o período em que seu teor de umidade permanece

ou se torna elevado. É um dos principais insumos para o segmento produtivo, sendo utilizado com destaque no arraçoamento de animais, em especial na suinocultura, na avicultura e na bovinocultura de leite, tanto na forma in natura como na forma de farelo, de ração ou de silagem. Na alimentação humana, o milho é comumente empregado na forma in natura, como milho verde, e na forma de sub-produtos, como pão, farinha e massas. Na indústria, é empregado como matéria-prima para produção de amido, óleo, farinha, glicose, produtos químicos, rações animais e na elaboração de formulações alimentícias. Porém, pesquisas recentes têm revelado novas utilidades para o cereal (Bull \& Cantarella, 1993).

A conservação do milho é de interesse fundamental porque sua produção se restringe a um curto período e o abastecimento ocorre durante todo ano. $\mathrm{O}$ interesse na melhor e mais prolongada conservação do grão é tanto maior quanto mais numerosos forem os agentes naturais que cooperam para sua deterioração e quanto mais fácil for a sua proliferação. Os 
grãos, sendo estruturas vivas, tendem a se deteriorar por um processo natural. Em condições ambientais favoráveis ao processo, tais como alto conteúdo de umidade do grão e temperatura elevada, o fenômeno da respiração, representado pela combustão de matéria seca em presença de oxigênio, anidrido carbônico e água, é o responsável direto pela evolução da deterioração. Inúmeros fatores podem influir no processo, como a espécie de semente utilizada no plantio, as condições climáticas desfavoráveis na colheita, os danos mecânicos, a secagem inadequada e o armazenamento impróprio (Fancelli, 1983).

Sérios danos podem ser causados por fungos em grãos estocados: aquecimento, emboloramento, redução do valor nutricional e produção de micotoxinas são algumas das alterações que podem tornar os grãos impróprios para o consumo, resultando em grandes perdas econômicas (Paster \& Bullerman, 1988). A respiração dos fungos libera calor, dióxido de carbono e água, provocando o aumento da temperatura e da umidade dos grãos, favorecendo o crescimento de fungos. Em casos extremos os grãos tornam-se negros e carbonizados (Christensen et al., 1969).

\section{2 - Aspergillus flavus e Aflatoxinas}

As espécies do gênero Aspergillus são, provavelmente, as mais implicadas na deterioração de alimentos. Morfologicamente, caracterizam-se pelo desenvolvimento de colônias coloridas e brilhantes e produção de conídios em cabeças do tipo "mop-like" (escovão), típicas. Dentro do gênero, a espécie A. flavus destaca-se por ser a mais importante produtora de aflatoxinas. Suas colônias são caracteristicamente verdes a amarelo-oliva (FIG. 1 e 2), embora eventualmente possam apresentar-se amarelo-puro, tornando acinzentadas com a idade. Aproximadamente $50 \%$ das cepas de A. flavus são produtoras de aflatoxinas (Geisen, 2000). Longos conidióforos sustentam cabeças conidiais que são tipicamente radiados, com 
vesículas globosas a subglobosas e com esclerócios pretos presentes em 50\% das cepas. O fungo apresenta afinidade particular por determinados substratos tais como amêndoas e sementes oleaginosas, sendo o amendoim, o milho e o algodão culturas mais atingidas e economicamente mais importantes. Outros alimentos usualmente contaminados por A. flavus são os condimentos, os alimentos preparados a partir de cereais, as farinhas e o pão (Pitt \& Hocking, 1985).

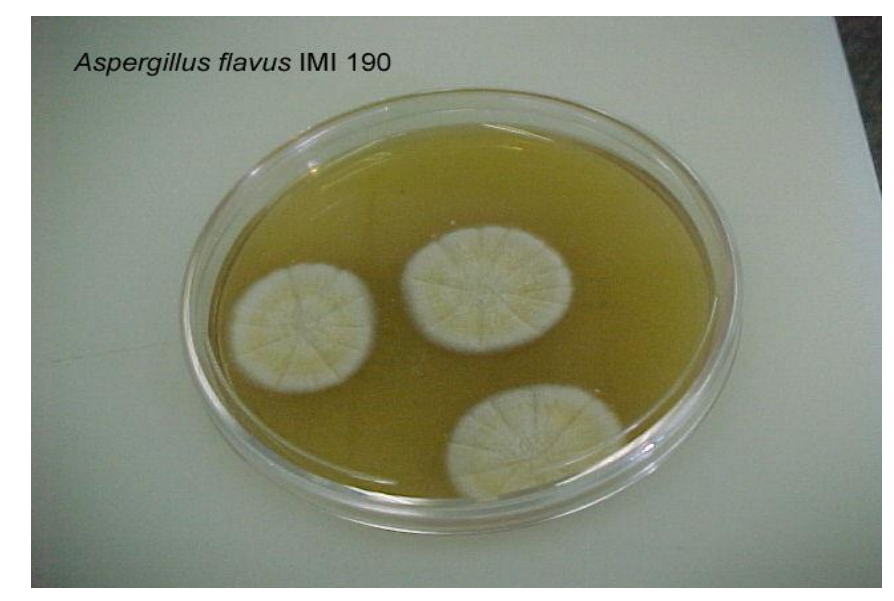

FIGURA 1. Placa de Agar A. flavus e parasiticus (AFPA) com colônias de A. flavus

FIGURA 2. Colônia gigante de Aspergillus flavus em Agar Batata Dextrose (PDA) 
As aflatoxinas são metabólitos secundários altamente tóxicos produzidos por espécies do gênero Aspergillus, principalmente A. flavus Link, A. parasiticus Speare e A. nomius. Quimicamente, as aflatoxinas são cumarinas substituídas ligadas a deidrofurano (FIG. 3). São conhecidas 17 substâncias do grupo, entretanto, as mais importantes em alimentos são as aflatoxinas $B_{1}, B_{2}, G_{1}$ e $G_{2}$. A aflatoxina $B 1$ é a mais tóxica seguida da $G_{1}, B_{2}$ e $G_{2}$. (Wyllie \& Morehouse, 1977).

As quatro substâncias são distinguidas com base nas suas fluorescências, ou seja, a aflatoxina $\mathrm{B}_{1}\left(\mathrm{AFB}_{1}\right)$ e a aflatoxina $\mathrm{B}_{2}\left(\mathrm{AFB}_{2}\right)$ emitem fluorescência azul (blue), $\mathrm{A}$ aflatoxina $\mathrm{G}_{1}\left(\mathrm{AFG}_{1}\right)$ e a aflatoxina $\mathrm{G}_{2}\left(\mathrm{AFG}_{2}\right)$ emitem fluorescência verde (green). A. flavus produz somente as aflatoxinas $\mathrm{B}_{1}$ e $\mathrm{B}_{2}$, enquanto $A$. parasiticus e $A$. nomius produzem as quatro toxinas. Foi demonstrado, em uma variedade de espécies animais, que a aflatoxina $\mathrm{B}_{1}$ é o mais potente carcinogênico de fígado que se conhece. A carcinogenicidade em animais é tão elevada que qualquer esforço deve ser feito para monitorar e reduzir os níveis em alimentos humanos (Pitt \& Hocking, 1999).

De acordo com Stoloff (1977) as aflatoxinas produzem quatro efeitos distintos: danos agudos ao fígado, cirrose de fígado, indução de tumores e efeitos teratogênicos. As aflatoxinas estão entre os mais importantes carcinógenos conhecidos, sendo classificadas na classe 1 dos carcinógenos humanos pela "International Agency for Research on Câncer” (IARC, 1993).

As aflatoxinas são estáveis ao calor sendo decompostas à temperatura de cerca de $220{ }^{\circ} \mathrm{C}$ (Van Der Zijden et al., 1962). São destruídas por agentes oxidantes fortes e, devido à presença do anel lactona, são susceptíveis à ação de base (Magoon et al., 1970). Apresentam baixo peso molecular, são bastante solúveis em solventes moderadamente polares como o clorofórmio, metanol, dimetilsulfóxido e pouco solúveis em água. Apresentam ponto de fusão ao redor de 
$269^{\circ} \mathrm{C}$ (TAB.1), são particularmente sensíveis à luz ultravioleta, principalmente quando dissolvidas em soluções polares e são destruídas por autoclavação em presença de amônia e por tratamento com hipoclorito (WHO, 1979).

TABELA 1. Propriedades químicas das aflatoxinas

\begin{tabular}{cccccc}
\hline Aflatoxina & $\begin{array}{c}\text { Fórmula } \\
\text { molecular }\end{array}$ & $\begin{array}{c}\text { Peso } \\
\text { molecular }\end{array}$ & $\begin{array}{c}\text { Ponto de } \\
\text { Fusão }\left({ }^{\circ} \mathrm{C}\right)\end{array}$ & $\begin{array}{c}\text { Absorção } \\
362-363 \mathrm{~nm}\end{array}$ & $\begin{array}{c}\text { Emissão de } \\
\text { fluorescência (nm) }\end{array}$ \\
\hline $\mathrm{B}_{1}$ & $\mathrm{C}_{17} \mathrm{H}_{12} \mathrm{O}_{6}$ & 312 & $268-269$ & 21800 & 425 \\
$\mathrm{~B}_{2}$ & $\mathrm{C}_{17} \mathrm{H}_{14} \mathrm{O}_{6}$ & 314 & $286-289$ & 23400 & 425 \\
$\mathrm{G}_{1}$ & $\mathrm{C}_{17} \mathrm{H}_{12} \mathrm{O}_{7}$ & 328 & $244-246$ & 16100 & 450 \\
$\mathrm{G}_{2}$ & $\mathrm{C}_{17} \mathrm{H}_{14} \mathrm{O}_{7}$ & 330 & $237-240$ & 21000 & 450 \\
\hline
\end{tabular}

Fonte - Butler, 1974 


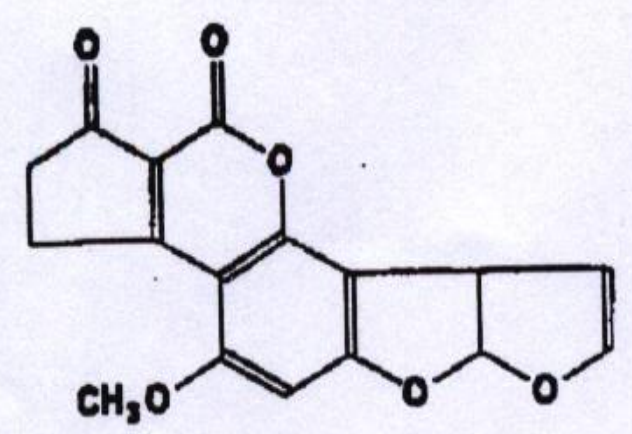

Anatoxina $\mathbf{B}_{1}$

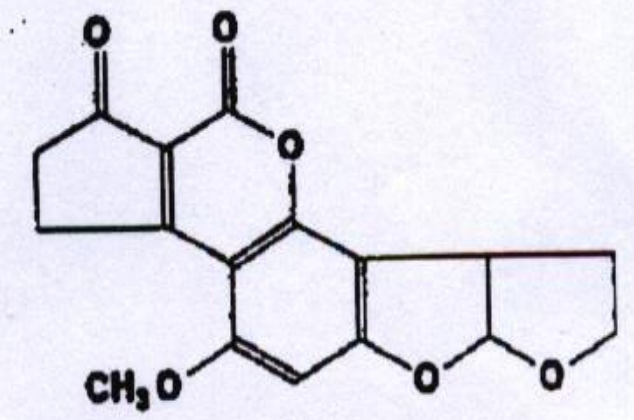

Anatoxina $B_{2}$

Fonte - Orsi, 1995.

FIGURA 3 : Estruturas químicas das aflatoxinas $\mathrm{AFB}_{1}$ e $\mathrm{AFB}_{2}$.

No Brasil, a presença de aflatoxinas em milho é atualmente regulada pela Resolução $\mathrm{n}^{\circ}$ 274 de 15 de outubro de 2002, da Agência Nacional de Vigilância Sanitária, que estabelece o limite de $20 \mu \mathrm{g} / \mathrm{kg}$ para a soma das aflatoxinas $\mathrm{B}_{1}, \mathrm{~B}_{2}, \mathrm{G}_{1}$ e $\mathrm{G}_{2}$, e pela Portaria $\mathrm{n}^{\circ} 183$ de 21 de março de 1996, do Ministério da Agricultura, do Abastecimento e da Reforma Agrária que estabelece o limite máximo de $20 \mu \mathrm{g} / \mathrm{kg}$, para somatória das aflatoxinas $\mathrm{B}_{1}, \mathrm{~B}_{2}, \mathrm{G}_{1}$ e $\mathrm{G}_{2}$, acompanhando o que foi estabelecido para os países do Mercosul (Brasil, 2002; Brasil, 1996). A TAB. 2 mostra os níveis de aflatoxinas de diversos produtos, determinadas pelo "U. S. Food and Drug Administration (FDA)" e a FIG. 4, os países que apresentam ou não regulamentação dos níveis de micotoxinas em alimentos. 
TABELA 2. Níveis totais de aflatoxinas em alimentos estabelecidos pelo "U. S. Food and Drug Administration (FDA)"

Produto
Concentração (ng/g ou $\mu \mathrm{g} / \mathrm{kg})$

Todos os produtos, exceto leite, designados para consumo humano

20

Milho para alimentação de animais jovens e gado leiteiro 20

Produtos de milho e amendoim para gado de corte, suínos e aves adultas $\quad 100$

Produtos de milho e amendoim para suínos de abate 200

Produtos de milho e amendoim para gado de corte de abate 300

Alimentos a base de semente de algodão (como ingrediente alimentar) 300

Todas as outras matérias- primas alimentares 20

Leite (aflatoxina $\mathrm{M}_{1}$ )

Fonte - Council for Agricultural Science and Technology, 2003. 


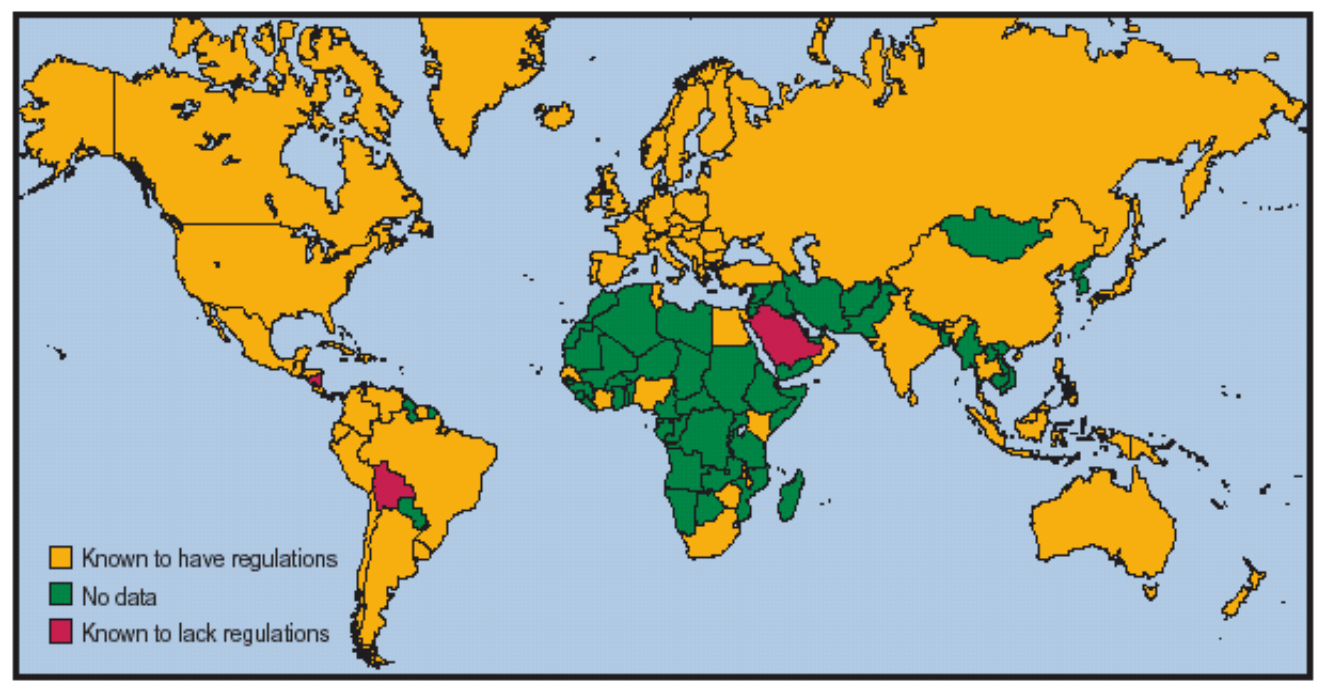

Fonte - FAO, 1997

FIGURA 4. Países que possuem regulamentos sobre micotoxinas em alimentos (amarelo), países onde não se sabe se existem regulamentos (verde) e nações que não possuem regulamentos específicos (vermelho).

\section{3- Condições para o crescimento de A. flavus e produção de aflatoxinas em milho}

Wilson et al. (1981) verificaram que no caso de grãos de milho, os principais fatores que afetam o desenvolvimento fúngico são o conteúdo de umidade dos grãos, a temperatura, a umidade relativa do ambiente, o tempo de armazenamento, a oxigenação, as condições dos grãos antes da colheita e a quantidade de inoculo presente no grão antes do armazenamento. De acordo com Almeida (1996), baseando-se nessas considerações, fica evidente a importância de se avaliar o comportamento dos diferentes microrganismos frente aos fatores intrínsecos (conteúdo de umidade e atividade de água) e aos fatores extrínsecos (temperatura, umidade relativa do ambiente e outros). 
Northolt et al. (1977) verificaram que a atividade de água do substrato desempenha papel importante no crescimento fúngico e produção de micotoxinas. De modo geral, os estudos mostraram que as aflatoxinas podem ser produzidas em condições de atividade de água e temperaturas próximas daquelas mínimas para o crescimento de Aspergillus flavus.

A água é, provavelmente, o mais importante determinante ecológico do crescimento fúngico em produtos estocados, embora outros fatores como, temperatura e composição gasosa intergranular também sejam relevantes. Mas nem toda a água presente está igualmente disponível para a colonização de microrganismos, pois parte está fortemente presa por ligações químicas ao substrato. Os valores de $A a$ oscilam entre 0 e 1 , sendo que a $A a$ da maioria dos alimentos frescos é superior a 0,99 (Jay, 1978).

A facilidade com que a porção fracamente ligada pode ser removida depende do conteúdo de água do substrato. A disponibilidade de água no substrato determina não somente quais microrganismos são capazes de se desenvolver, mas também, a taxa de germinação dos esporos e subseqüente crescimento, suas interações com outros fungos, habilidade em produzir esporos e atividades metabólicas (Lacey, 1988).

Atualmente, aceita-se, de maneira geral, que as necessidades dos microrganismos devem ser expressas em termos de $A a$ do substrato (Jay, 1978). A $A a$ tem sido definida como a relação entre a pressão de vapor da solução $\mathrm{P}$ (solutos em água, na maioria dos alimentos) e a pressão de vapor $\mathrm{P}_{0}$ (usualmente a água). Isto pode ser expresso matematicamente pela Lei de Raoult:

$$
A a=\mathbf{P} / \mathbf{P}_{0}=\mathbf{n}_{1} / \mathbf{n}_{1}+\mathbf{n}_{2}
$$


Onde, $\mathrm{P}$ é a pressão de vapor de uma solução, $\mathrm{P}_{0}$ é a pressão de vapor da água pura, $\mathrm{n}_{1}$ é o número de moles do solvente e $\mathrm{n}_{2}$ é o número de moles do soluto. A umidade relativa (UR) é reservada para caracterizar condições atmosféricas (Troller et al., 1984). Este conceito está, ainda, associado com a umidade relativa (UR) da seguinte forma (Christian, 1963):

\section{$\mathrm{UR}=100 \times A a$}

A $A a$ está relacionada com a Umidade Relativa em Equilíbrio (ERH) da seguinte maneira:

$$
A a=\frac{\mathrm{ERH}}{100}
$$

A Aa mínima para crescimento de A. flavus é 0,71 a 0,74 , com valor ótimo de 0,98, sendo a $A a$ mínimo para a produção de toxina em torno de 0,82 e temperatura compreendendo entre 25 a $37{ }^{\circ} \mathrm{C}$ (Smith, D. et al., 1994). Segundo Pitt \& Miscamble (1995) a atividade de água mínima para germinação e crescimento é 0,82 a $25^{\circ} \mathrm{C} ; 0,81$ a $30{ }^{\circ} \mathrm{C}$ e 0,80 a $37^{\circ} \mathrm{C}$. A $A a$ mínima e faixa de temperatura ótima para a formação de micotoxinas do gênero Aspergillus são demonstrados na TAB. 3. Hunter (1969) propôs o valor de 0,87 como sendo o limite mínimo de $A a$ para a produção de aflatoxina em grãos de milho.

Segundo Diener et al. (1970), não somente a Aa parece influenciar o desenvolvimento fúngico. O teor de umidade dos grãos também é um fator de fundamental importância no controle microbiológico dos alimentos, em razão de que abaixo de determinados teores de umidade o A. flavus tem seu crescimento comprometido. 
TABELA 3. Temperatura e Atividade de água $(A a)$ mínima para o crescimento e produção de micotoxinas das principais espécies toxigênicas do gênero Aspergillus

\section{Aa mínima}

\begin{tabular}{llll} 
& $\begin{array}{c}\text { Temperatura } \\
\text { Fungo }\end{array} \quad\left({ }^{\circ} \mathrm{C}\right)$ faixa ótima & & \\
\cline { 3 - 3 } & & Crescimento & $\begin{array}{c}\text { Produção de } \\
\text { micotoxinas }\end{array}$
\end{tabular}

$\begin{array}{lccccc}\text { A. flavus } & 6-45 & 35 & 0,78-0,80 & 0,83-0,87 & \text { aflatoxinas } \\ \text { A. ochraceus } & 10-35 & 25 & 0,76-0,83 & 0,83-0,87 & \text { ocratoxinas } \\ \text { A. parasiticus } & 6-45 & 35-37 & 0,78-0,82 & 0,87 & \text { aflatoxinas } \\ \text { A. clavatus } & 10-37 & 25 & 0,85 & 0,99 & \text { patulina } \\ \text { A. fumigatus } & 10-55 & 40-42 & 0,82-0,94 & \mathrm{nd}^{*} & \text { fumigatoxina e } \\ & & & & & \text { gliotoxina } \\ \text { A. versicolor } & 4-39 & 25-30 & 0,78 & & \text { patulina e } \\ & & & & & \text { esterigmatocistina }\end{array}$

Fonte - Leitão, 1988 e Lacey 1991.

*Não determinado

Trenk \& Hartmann (1970) observaram pouco crescimento de A. flavus em grãos de milho com teores de umidade abaixo ou igual a 16\%. Porém, quando este atingia 17\%, o crescimento do fungo e a produção de aflatoxina se elevavam e, ainda, quando este valor atingia 18\%, o crescimento do A. flavus aumentava rapidamente. Diner \& Davis (1970) observaram que a germinação e a esporulação do Aspergillus flavus ocorre entre 81 a $83 \%$ de umidade relativa do ar. Entretanto, acima de $85 \%$, o fungo desenvolve-se e produz aflatoxinas. Neste trabalho, os autores concluíram que um pequeno acréscimo na umidade relativa aumentaria o risco de contaminação pela micotoxina. 
Diner \& Davis (1966), observaram, em meio de cultura, a produção máxima de aflatoxinas por Aspergillus flavus em temperatura de $25{ }^{\circ} \mathrm{C}$, por 7 a 9 dias de incubação. $\mathrm{O}$ gênero Aspergillus cresce prontamente em temperaturas entre 15 e $30^{\circ} \mathrm{C}$ (TAB. 4).

TABELA 4. Temperatura média para o crescimento de algumas espécies de Aspergillus

\begin{tabular}{lcc}
\hline Espécies & \multicolumn{2}{c}{ Temperatura $\left({ }^{\circ} \mathrm{C}\right)$} \\
& Média & Ótima \\
\hline A. restrictus & $9-40$ & $25-30$ \\
A. clavatus & $5-42$ & 25 \\
A. fumigatus & $12-65$ & $37-45$ \\
A. flavipes & $6-40$ & $26-28$ \\
A. terreus & $11-48$ & $35-40$ \\
A. ustus & $6-42$ & $25-28$ \\
A. sydowii & $>5-40$ & 25 \\
A. versicolor & $4-40$ & $21-30$ \\
A. candidus & $3-44$ & $25-32$ \\
A. ochraceus & $12-37$ & 27 \\
A. flavus & $6-45$ & $25-37$ \\
A. niger & $9-60$ & $17-42$ \\
\hline
\end{tabular}

Fonte - Lacey \& Magan 1991

\section{4 - Efeitos e mecanismos da radiação ionizante}

A característica da radiação de alta energia é causar ionização no meio em que é absorvida, ou seja, é capaz de remover elétrons de suas órbitas em átomos ou moléculas. Por esta razão é denominada de radiação ionizante. As radiações ionizantes cedem sua energia ao 
meio no qual se difundem, mediante múltiplos processos de interação. A energia cedida é gasta na excitação e na ionização de moléculas gerando reações químicas que podem provocar modificações permanentes na estrutura físico-química do material irradiado. A dose absorvida, ou simplesmente dose, é a quantidade de energia absorvida por unidade de massa do material irradiado. A unidade utilizada denomina-se Gray (Gy), onde 1 Gy é equivalente à energia de 1 joule absorvido por $1 \mathrm{~kg}$ de material (Satin, 1993).

As radiações utilizadas no processamento de alimentos não possuem energia suficiente para provocar qualquer reação nuclear na matéria e, portanto, não deixam nenhum resíduo radioativo no material após a irradiação. Por esta razão, o alimento ou qualquer outro material submetido a esse tipo de radiação não se torna radioativo (Maxy, 1992; IAEA,FAO, WHO,1999).

\subsection{1- Radiólise da água e seus produtos}

A água está presente em quase todos os alimentos, numa proporção em torno de $90 \%$ em muitos vegetais, $80 \%$ em frutas, $60 \%$ na carne e $40 \%$ no pão. Mesmo produtos aparentemente mais secos contêm água: farinha de trigo $13 \%$, vegetais desidratados cerca de $10 \%$ e nozes $5 \%$. A radiólise da água é, portanto, de particular interesse em irradiação de alimentos (Diehl, 1995). Os produtos da radiólise da água são (WHO, 1994):

$\bullet \mathrm{OH}$ - radical hidroxila

$\mathrm{e}^{-}$aq - elétron aquoso (ou hidratado)

•H - átomo de hidrogênio

$\mathrm{H}_{2}$ - hidrogênio

$\mathrm{H}_{2} \mathrm{O}_{2}$ - peróxido de hidrogênio

$\mathrm{H}_{3} \mathrm{O}^{+}\left(=\mathrm{H}^{+}{ }_{\mathrm{aq}}\right)$ - próton hidratado 
Enquanto $\bullet \mathrm{OH}$, e ${ }_{\text {aq }}^{-}$e $\bullet \mathrm{H}$ são espécies reativas transitórias, $\mathrm{H}_{2}$ e $\mathrm{H}_{2} \mathrm{O}_{2}$, são os únicos produtos da radiólise da água estáveis. Por causa das reações (demonstradas abaixo) hidrogênio e peróxido de hidrogênio são largamente consumidos.

$$
\begin{aligned}
& \mathrm{H}_{2} \mathrm{O}_{2}+\mathrm{e}_{\text {aq }}^{-} \rightarrow \cdot \mathrm{OH}+\mathrm{OH}^{-} \\
& \mathrm{H}_{2}+\bullet \mathrm{OH} \rightarrow \mathrm{H}_{2} \mathrm{O}+\bullet \mathrm{H}
\end{aligned}
$$

Eles são consequentemente produzidos em baixas quantidades, mesmo quando as doses de irradiação são altas. A saturação da água com oxigênio pode aumentar intensamente a produção de $\mathrm{H}_{2} \mathrm{O}_{2}$. A formação de peróxido de hidrogênio $\left(\mathrm{H}_{2} \mathrm{O}_{2}\right)$, conhecido por ser um agente oxidante, têm grande significado na irradiação de alimentos. O radical hidroxila $(\bullet \mathrm{OH})$ é um poderoso agente oxidante e o elétron aquoso $\left(\mathrm{e}^{-} \mathrm{aq}\right)$ é um forte agente redutor. $\mathrm{O}$ átomo de hidrogênio $(\bullet \mathrm{H})$ é um agente redutor menos efetivo. Considerando que todos os alimentos contêm substâncias que podem ser oxidadas ou reduzidas, as reações acima descritas são esperadas quando alimentos que contêm água são irradiados (Diehl, 1995).

\subsection{2- Influência do Oxigênio}

A presença ou ausência de oxigênio durante a irradiação tem uma importante influência no curso da radiólise. A água, em equilíbrio com o oxigênio do ar, contem baixas concentrações de oxigênio (cerca de $0,27 \mathrm{mM}$ a temperatura ambiente). Átomos de hidrogênio podem reduzir o oxigênio formando o radical hidroperóxido, que é um agente oxidante fraco (WHO, 1994):

$$
\bullet \mathrm{H}+\mathrm{O}_{2} \rightarrow \cdot \mathrm{HO}_{2}
$$

Em equilíbrio com radical ânion superóxido:

$\bullet \mathrm{HO}_{2} \leftrightarrow \mathrm{H}^{+}+\bullet \mathrm{O}_{2}^{-}$ 
Outro caminho para formação do radical superóxido é a reação de elétron aquoso com oxigênio:

$\mathrm{e}_{\mathrm{aq}}^{-}+\mathrm{O}_{2} \rightarrow \cdot \mathrm{O}^{-}$

Através da remoção de agentes redutores $\left(\mathrm{e}^{-}\right.$aq $\left.\mathrm{e} \cdot \mathrm{H}\right)$, a importância do radical $\bullet \mathrm{OH}$ e portanto o papel das reações de oxidação se torna maior em soluções oxigenadas. Ambos radical hidroperóxido $\left(\bullet \mathrm{HO}_{2}\right)$ e radical superóxido $\left(\bullet \mathrm{O}_{2}^{-}\right)$podem causar o aumento de do peróxido de hidrogênio $\left(\mathrm{H}_{2} \mathrm{O}_{2}\right)$ :

$2 \cdot \mathrm{HO}_{2} \rightarrow \mathrm{H}_{2} \mathrm{O}_{2}+\mathrm{O}_{2}$

$\cdot \mathrm{O}_{2}^{-}+\cdot \mathrm{HO}_{2}+\mathrm{H}^{+} \rightarrow \mathrm{H}_{2} \mathrm{O}_{2}+\mathrm{O}_{2}$

Como demonstrado anteriormente, muitos outros radicais são produzidos quando os alimentos são irradiados. O oxigênio pode acrescentar alguns dos radicais, levando ao aumento de radicais peróxidos (Grant, 1991).

\subsection{3- Influência da temperatura}

A temperatura, durante a irradiação, também influencia a extensão de mudanças radiolíticas. O congelamento produz um forte efeito protetor para o ácido ascórbico, por exemplo. Como mencionado anteriormente, as reações intermediárias da radiólise da água são interrompidas em materiais congelados e são, desta forma, mantidos inertes das reações entre os radicais ou com o substrato. Quando o material alcança novamente temperatura ambiente, os danos no substrato são muito menores do que em produtos não congelados, quando irradiados. O congelamento não significa uma completa restrição da difusão. A difusão de moléculas e radicais livres é maior em temperatura de $-2{ }^{\circ} \mathrm{C}$ do que a $-10^{\circ} \mathrm{C}$, e a $-10^{\circ} \mathrm{C}$ mais do que $80{ }^{\circ} \mathrm{C}$ (Ley, 1970). 


\subsection{5- Efeitos da diluição}

Quando uma solução diluída é irradiada, a extensão da degradação do soluto depende do número de radicais reativos disponíveis para a reação com as moléculas do soluto. A enzima pectinase apresenta uma alta radioresistência quando irradiada em estado seco, mas é amplamente inativada quando irradiada em soluções. $\mathrm{O}$ aumento da radiosensibilidade com o aumento da diluição é conhecido como efeito da diluição (Farkas, 1985).

\section{4.6 - Efeitos biológicos da radiação ionizante}

Quando a radiação ionizante é absorvida por um material biológico, existe a possibilidade de que esta irá agir diretamente em alvos críticos na célula. As moléculas de ácido nucléico podem ser ionizadas ou excitadas, e por meio disso, iniciar a cadeia de eventos que conduzem às mudanças biológicas e à morte celular, se a mudança é suficientemente séria. Este é o efeito direto da radiação, o qual é o processo dominante quando esporos secos de microrganismos são irradiados. Alternativamente, a radiação pode interagir com outros átomos ou moléculas na célula, particularmente água, para produzir radicais livres, os quais podem difundir-se o bastante para alcançar e danificar o DNA. Este efeito indireto da radiação é importante em células vegetativas, onde o citoplasma contem cerca de $80 \%$ de água (Diehl, 1995).

As doses de radiação causam pequenas mudanças químicas em alimentos, mas causa mudanças letais em uma célula bacteriana. Isto ocorre uma vez que o DNA tem uma propriedade particular diferenciada de todos os outros constituintes da célula.

1. O DNA carrega as informações genéticas. A seqüência de purinas e pirimidinas na cadeia de DNA serve como template para montar uma cópia de DNA no processo de divisão celular. 
2. Através dos templates de RNA (ácido ribonucléico) esta seqüência determina a síntese de proteína, incluindo as enzimas que regulam o metabolismo celular.

3. Moléculas de DNA são enormes em comparação com outras moléculas na célula e com isso, gera um grande alvo.

4. A função do DNA como carreador de informação genética depende da molécula intacta.

5. Somente uma cópia (ou poucas cópias) de uma molécula de DNA está presente na célula.

Considerando que a sensibilidade à radiação de macromoléculas é aproximadamente proporcional ao seu peso molecular, Pollard (1966), estimou que uma dose de 0,1 kGy danificaria 2,8\% do DNA numa célula bacteriana enquanto que a mesma dose danificaria $0,14 \%$ das enzimas e somente $0,005 \%$ dos amino ácidos.

O dano correspondente a 2,8 \% do DNA seria letal para uma ampla fração das células irradiadas, e isto teria conseqüências as quais são facilmente reconhecidas a olho nu: poucas colônias desenvolvidas quando inoculadas em meios de cultura. Efeitos da quebra do DNA em alimentos processados por radiação são mostrados por diversos autores (Villavicencio, 2000; Delincée, 2002). Em contraste, o dano de $0,14 \%$ causado às moléculas das enzimas, seria difícil de ser detectado, mesmo com métodos analíticos sofisticados, e uma mudança de 0,005\% nos amino ácidos em sistemas biológicos não pode ser detectada. Essas considerações explicam porque uma dada dose pode ter um efeito letal nos microrganismos em uma amostra de alimento irradiado, sem causar muita alteração na composição química do alimento.

\section{5- Efeitos da radiação ionizante em alimentos}

O processamento de alimentos por radiação requer uma exposição controlada e cuidadosa frente à radiação ionizante de energia conhecida. A exposição deve ser adequada para produzir 
um resultado desejado, evitando, ao mesmo tempo, a degradação do alimento. O tipo de irradiação utilizado no tratamento de alimentos se limita às radiações provenientes dos raios gama de alta energia, os raios X e os elétrons acelerados (WHO, 1994).

As fontes de radiação utilizadas para a irradiação de alimentos são: os raios gama dos radionuclídeos Cobalto 60 ou Césio 137; raios-X gerados por máquinas com energia máxima de $5 \mathrm{MeV}$ e feixes de elétrons com uma energia máxima de $10 \mathrm{MeV}$. Dos radionuclídeos o ${ }^{137}$ Cs praticamente não é mais utilizado, devido a sua baixa disponibilidade. Portanto, o ${ }^{60}$ Co é a única fonte de raios gama de interesse prático. As vantagens da fonte de ${ }^{60}$ Co são (Matsuda, 2002):

- Alta penetração e dose uniforme, permitindo o tratamento de produtos de tamanho, forma e densidades variáveis;

- Uso comprovado por longa data em aplicações industriais;

- Fácil utilização da fonte;

- Baixo risco ambiental.

Desvantagens:

- Meia-vida de 5, 263 anos, o que significa que 12\% da atividade da fonte deve ser substituída anualmente para manter a potência original;

- Baixa taxa de dose.

A irradiação inativa os organismos que decompõem os alimentos, em particular as bactérias, os mofos e as leveduras. É muito eficaz para prolongar o tempo de conservação de frutas frescas e hortaliças, pois, controla as mudanças biológicas normais associadas à maturação, à germinação e, por último, ao envelhecimento. A irradiação também destrói os 
microrganismos causadores de doenças, inclusive os vermes parasitas e os insetos que deterioram os alimentos armazenados (OMS, 1989).

A irradiação deve ser aplicada em alimentos já embalados, porém não evita a recontaminação ou a reinfestação. A qualidade do alimento irradiado, bem como o de outro alimento, é função da qualidade do produto original, que deverá ser produzido segundo as boas práticas de fabricação (Farkas, 1985, Villavicencio, 1998). A eficácia da ação bactericida e fungicida de uma determinada dose de radiação depende dos seguintes fatores:

- Tipo e espécie de microrganismos;

- Número de microrganismos (ou esporos) existentes inicialmente;

- Composição do alimento. É possível que alguns constituintes do alimento, por exemplo, as proteínas, a catalase e as substâncias redutoras exerçam sobre os microrganismos uma ação protetora;

- Existência ou falta de oxigênio;

- Estado físico do alimento durante a irradiação. Tanto a quantidade de umidade como a temperatura do alimento exerce uma influência diferente nos microrganismos;

- Fatores próprios dos microrganismos. A idade, a temperatura de crescimento e a da esporulação, e o estado (células vegetativas ou esporuladas) podem influir no nível de sensibilidade dos microrganismos (Murano, 1995). 
A TAB. 5 apresentam dados de diferentes procedências, relativos às doses aproximadas de radiação necessárias para destruir diferentes tipos de microrganismos.

TABELA 5. Doses letais aproximadas de radiação ionizante

\begin{tabular}{lclc}
\hline Organismos & $\begin{array}{c}\text { Doses letais } \\
\text { aproximadas (kGy) }\end{array}$ & Microrganismos & \multicolumn{2}{c}{$\begin{array}{c}\text { Doses letais } \\
\text { aproximadas (kGy) }\end{array}$} \\
\hline Humanos & $0,0056-0,0075$ & Escherichia coli (G-) & $1,0-2,3$ \\
Insetos & $22-93$ & Pseudomonas aeruginosa (G-) & $1,6-2,3$ \\
Vírus & $10-40$ & Enterobacter aerogenes (G-) & $1,4-1,8$ \\
Leveduras & $4-9$ & Lactobacillus spp. (G+) & $0,23-0,38$ \\
(fermentativas) & & Bacillus subtilis (esporos) & $12-18$ \\
Torula cremosis & 4,7 & Clostridium botulinum (A) (esporos) & $19-37$ \\
S. cerevisae & 5 & Clostridium botulinum (B) (esporos) & $15-18$ \\
Candida krusei & 11,6 & Clostridium perfringens (esporos) & 3,1 \\
Mofos (com esporos) & $1,3-11$ & Bacillus stearothermophilus (esporos) & $10-17$ \\
Penicillium spp. & $1,4-2,5$ & Mycobacterium tuberculosis & 1,4 \\
Aspergillus spp. & $1,4-3,7$ & Staphylococcus aureus & $1,4-7$ \\
Rhizopus sp. & 10 & Corynebacterium diphtheriae & 4,2 \\
Fusarium sp. & 2,5 & Salmonella sp. & $3,7-4,8$ \\
\hline
\end{tabular}

Fonte - Frazier, 1993

Geralmente os organismos mais simples são mais resistentes aos efeitos da radiação ionizante. Por exemplo, os vírus são mais resistentes do que as bactérias, as quais são mais resistentes que os bolores que, por sua vez, são mais resistentes que os seres humanos. A diferença na resistência do microrganismo não se restringe somente aos gêneros, mas também entre linhagens de uma mesma espécie (Monk, 1995). 
A idade das culturas pode influenciar consideravelmente a radiosensibilidade e por isso, experimentos conduzidos por diferentes autores, para determinar a sensibilidade à radiação de leveduras e bolores, não apresentem resultados idênticos, contudo, leveduras são geralmente mais resistentes do que bolores (Münzner, 1969).

Em 1992, A WHO e a Americam Medical Association afirmaram que o alimento irradiado, produzido sob boas práticas de fabricação (BPF) deve ser considerado seguro e nutricionalmente adequado, pois:

- Não induz a alteração na composição do alimento, que do ponto de vista toxicológico, poderiam levar a efeitos adversos à saúde humana;

- Não introduz alterações na microflora do alimento, que poderiam aumentar o risco microbiológico para o consumidor;

- Não leva a perdas nutritivas, que poderiam impor efeitos adversos ao estado nutricional individual ou populacional (Spolaore et al., 2003).

A adequação nutricional dos alimentos irradiados é sumarizada em muitas revisões, as quais nos mostram claramente que as alterações ocorridas nos alimentos são mínimas ou mesmo, em alguns casos, nulas quando se é respeitada a dose certa para cada tipo de alimento (Diehl et al., 1994). Em geral, o processo de irradiação nas doses recomendadas, acarreta poucas alterações químicas nos alimentos. Segundo Diehl (1992; 1995), nas doses de até 1 kGy, as perdas nutricionais são consideradas insignificantes e nenhuma das alterações conhecidas encontradas nos alimentos irradiados é nociva ou perigosa, estando dentro dos limites encontrados normalmente para alimentos (Satin, 1993; Delincée et al., 1998). 


\section{6 - Legislação para irradiação de alimentos no Brasil e no mundo:}

De acordo com a WHO (1977), o Comitê Técnico que se reuniu em 1976 concluiu que a irradiação de qualquer produto alimentar, acima de uma média total de dose de $10 \mathrm{kGy}$, não apresenta perigos toxicológicos, e conseqüentemente, testes toxicológicos de alimentos, então irradiados, não seriam necessários. Uma dose de 10 kGy não introduz, em especial, problemas nutricionais ou microbiológicos (Aziz, 2000).

O ICGFI foi criado em 1984 pela Organização Mundial da Saúde (WHO), conjuntamente com a Organização das Nações Unidas para a Alimentação e Agricultura (FAO) e a Agência Internacional de Energia Atômica (IAEA), para estudar as diversas aplicações da irradiação de alimentos. Esse grupo vem acompanhando a evolução da aplicação dessa tecnologia a nível mundial. O Brasil, junto com mais 44 países, faz parte desse grupo (FIG.5). Somente os países Brasil, Chile e Argentina têm legislações sobre irradiação de alimentos e estas regulamentações diferem entre si principalmente em termos de alimentos que podem ser irradiados e doses aplicadas (Matsuda, 2002). 
TABELA 6. Regulamentação para irradiação aprovada pelo United States Food and Drug Administration (FDA).

\begin{tabular}{|c|c|c|c|}
\hline Produto & Propósito & Dose (kGy) & Data \\
\hline Trigo e farinha de trigo & Desinfestação & 0,2 a 0,5 & $21 / 08 / 63$ \\
\hline Batatas & Estender a vida útil e desinfestação & 0,05 a 0,15 & $01 / 11 / 65$ \\
\hline $\begin{array}{c}\text { Temperos vegetais secos e } \\
\text { especiarias }\end{array}$ & $\begin{array}{c}\text { Descontaminação e desinfestação de } \\
\text { insetos }\end{array}$ & 30 (máx) & $15 / 07 / 83$ \\
\hline $\begin{array}{c}\text { Prep. Enzimáticas secas ou } \\
\text { desidratadas }\end{array}$ & Controle de insetos e microrganismos & 10 (máx) & $10 / 06 / 85$ \\
\hline $\begin{array}{c}\text { Carcaças suínas, cortes frescos } \\
\text { ou processados }\end{array}$ & Controle de T. spiralis & 0,3 a 1,0 & $22 / 07 / 85$ \\
\hline Frutas frescas & Retardar maturação & 1 & $18 / 04 / 86$ \\
\hline $\begin{array}{c}\text { Prep. Enzimáticas secas ou } \\
\text { desidratadas }\end{array}$ & Descontaminação & 10 & $18 / 04 / 86$ \\
\hline $\begin{array}{l}\text { Substâncias vegetais } \\
\text { aromáticas secas ou } \\
\text { desidratadas }\end{array}$ & descontaminação & 30 & $18 / 04 / 86$ \\
\hline Frango & $\begin{array}{c}\text { Controle de microrganismos } \\
\text { patogênicos }\end{array}$ & 3 & $02 / 05 / 90$ \\
\hline
\end{tabular}

Fonte - Spolaore et al., 2003 


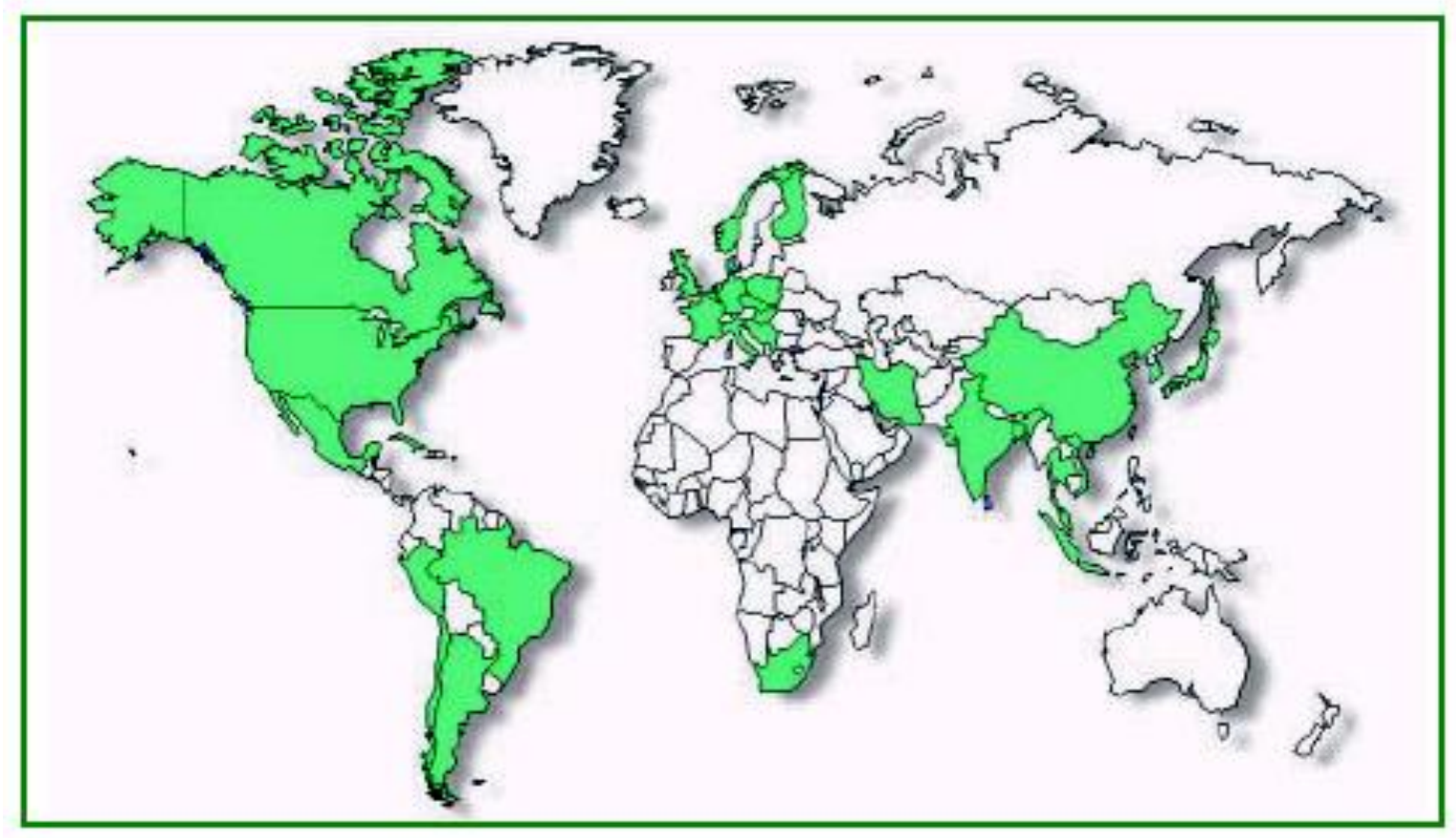

Fonte - ICGFI, 1999.

FIGURA 5. Utilização Mundial da Irradiação de Alimentos. Países que aplicam irradiação de alimentos com propósitos comerciais (em verde) e países que ainda não aplicam a irradiação de alimentos (branco).

No Brasil, os seguintes Decretos e Resoluções já publicados, são resumidos abaixo;

- $\quad$ Decreto - lei no 986 de 21 de Outubro de 1969

Estabelece normas gerais sobre alimentos

Início da movimentação sobre legislação brasileira sobre irradiação de alimento 
- $\quad$ Decreto lei $\mathrm{n}^{\circ} 72718$, de 29 de agosto de 1973

Estabelece normas gerais sobre irradiação de alimentos

Normas Gerais para processamento. Estocagem, transporte, importação e exportação , venda e consumo de alimentos irradiados. Estabelece o logo da Radura no Rótulo do produto irradiado.

- Portaria DINAL n ${ }^{\circ} 09$ de 8 de março de 1985 MS - Revogada pela RDC n 21 de 26/01/01

Aprovar normas gerais para irradiação de alimentos no Brasil, indicando para cada caso o tipo, nível e dose média de energia de radiação e o tratamento prévio conjunto ou posterior. Limitam dose a 10 kGy; Proíbem a re-irradiação.

- Portaria DINAL $\mathrm{n}^{\circ} 30$ de 25 de setembro de 1989- Revogada pela RDC n $^{\circ} 21$ de 26/01/01

Ampliando autorização a outros tipos de alimentos que não constavam da portaria anterior.

- Resolução ANVISA - RDC nº 21, de 26 de janeiro de 2001

Revoga as Portarias DINAL no 09 de 08/03/85 e no 30 de 25/09/89

“4.3. Dose absorvida: Qualquer alimento poderá ser tratado por radiação desde que sejam observadas as seguintes condições":

*a) A dose mínima absorvida deve ser suficiente para alcançar a finalidade pretendida;

b) A dose máxima absorvida deve ser inferior àquela que comprometeria as propriedades funcionais e ou os atributos sensoriais do alimento". 


\section{7 - PCR}

A reação de polimerização em cadeia, PCR (Polimerase Chain Reaction) é a técnica que permite a amplificação do DNA in vitro, utilizando-se basicamente de uma reação enzimática catalisada pela polimerase (enzima termoestável), cuja atividade depende de íons $\mathrm{Mg}++$ e ocorre em 3 etapas: "Melting" ou desnaturação, que consiste na separação da dupla fita do DNA a ser amplificado; "Annealing" ou hibridização, ligação do iniciador ou "primer" ao DNA a ser amplificado e "Extension" ou extensão, ou seja, a polimerização propriamente dita. (Saiki et al., 1988):

1. Desnaturação - Inicialmente é necessário que as duas fitas de DNA a serem amplificadas sejam separadas. A elevação da temperatura entre 90 a $95{ }^{\circ} \mathrm{C}$ promove a separação da fita dupla de DNA em duas fitas simples. Este procedimento é chamado "Desnaturação" ou "melting", e muitas vezes a temperatura de desnaturação é determinada empiricamente e depende de alguns fatores como a quantidade de guanina e citosina (GC) do fragmento DNA alvo ou de interesse.

2. Anelamento - A polimerase para assumir suas funções, isto é, anexar as bases complementares, transformando as fitas simples em fitas duplas, necessita de um fragmento de DNA já ligado na região previamente escolhida. A solução, então, é demarcar as extremidades do DNA procurado ou de interesse nas duas longas fitas simples, tornando-as duplas, apenas nesse intervalo. Para isso adicionam-se, à solução, os "primers" ou iniciadores que são pequenos fragmentos sintéticos de DNA de fita simples, oligonucleotídeos de 20 a 30 bases nitrogenadas de comprimento, que são sintetizados "in vitro" baseados na seqüência de do DNA a ser amplificado sendo eles complementares a seqüência do segmento de DNA de interesse. O conhecimento da sequiência procurada é naturalmente pré-requisito para a síntese dos "primers". Os "primers" perseguem na reação as regiões, as quais foram 
escolhidas, para hibridizar-se às seqüências complementares nas duas fitas simples (usualmente 5'). Nas duas fitas surgem, assim, um pequeno fragmento de DNA de dupla fita intacta. A hibridização dos "primers" descrito como "Anneling" (do inglês), deve ser feito a uma temperatura inferior à da desnaturação $\left(45\right.$ a $\left.60{ }^{\circ} \mathrm{C}\right)$.

3. Extensão- Quando os "primers" encontram e ligam-se aos segmentos complementares, a DNA-Polimerase pode assumir sua função. Inicia-se a partir dos pequenos fragmentos de DNA de fita dupla (resultado do anelamento do "primer"), incorporado um a um os nucleotídeos correspondentes, isto é, as bases juntamente com as moléculas de açúcar e fosfato. A DNA-Polimerase liga os nucleotídeos entre si, completando assim as fitas simples e tornando-as duplas (extensão). A DNA-Polimerase não reconhece apenas o bloco de início como também consegue diferenciar as duas extremidades dos "primers" (3'e 5'). Ela inicia a reação sempre pela extremidade 3' do "primer", completando a fita simples daí em diante, portanto, sempre na direção do fragmento procurado.

Os fragmentos de DNA recém-formados fornecem mais moldes para a montagem de novas fitas nos ciclos subseqüentes, no entanto, com região já determinada, resumindo, temos uma reação em cadeia. Após cada ciclo, o número de fragmentos se duplica: de um formando-se 2 , e então novamente $4,8,16,32,64,128$...de tal forma que pode ser definida matematicamente por:

$$
\mathbf{N}=\mathbf{N}_{\mathbf{0}} \times 2^{\mathbf{n}}
$$

$\mathrm{N}$ = número de moléculas amplificadas

$\mathbf{N}_{\mathbf{0}}$ = número de moléculas iniciais

$\mathrm{n}=$ número de ciclos de amplificação 
O modelo teórico considera que a eficiência do processo de amplificação corresponde a 100\%, o que não é observado na prática. Experimentalmente, a eficiência da reação está abaixo da ideal e gira em torno de $78 \%$ a $97 \%$, dependendo do gene amplificado. Teoricamente após 20 ciclos têm -se cerca de um milhão; após 30 ciclos, cerca de um bilhão de cópias do fragmento de DNA de interesse. Saiki et al., 1985; Mullis et al., 1986; Mullis \& Faloona, 1987 introduziram as diversas aplicações do PCR para a comunidade científica e atualmente é inesgotável a sua aplicação prática tanto na pesquisa básica como na aplicada. A PCR utilizando DNA polimerases termoestáveis foi descrita pela primeira vez por Kary Mullis e patenteada nos EUA sob o número 4.683.195, em julho de 1987 e número 4.683.202 (Hirata et al., 1999).

\section{8 - Método fluorescente para estudo de viabilidade}

Com a utilização do Diacetato de Fluoresceína (DF) como indicador da viabilidade de células de mamíferos (Rotman et al., 1966), intensificaram-se as investigações a fim de esclarecer o mecanismo da reação fluorocromática do DF, até chegarmos ao modelo hoje aceito (FIG.7), proposto por Medzon \& Brady (1969). Estudos realizados com Diacetato de Fluoresceína - DF (3,6 diacetil fluoresceína) (FIG. 6), concluíram que este era hidrolisado por diferentes enzimas, tais como esterases e proteases. O produto desta conversão enzimática resulta na fluoresceína que se acumulava intracelularmente (fluorocromasia), desde que a membrana celular estivesse intacta, facilmente detectável sob luz ultravioleta, apresentando coloração verde brilhante (Guibault \& Klamer, 1964). A fluoresceína pode ser visualizada através de microscopia de fluorescência por sua fluorescência verde brilhante. O mecanismo de ação da reação fluorocromática de células vivas (Medzon \& Brady, 1969), pode ser visualizado na FIG. 7. 


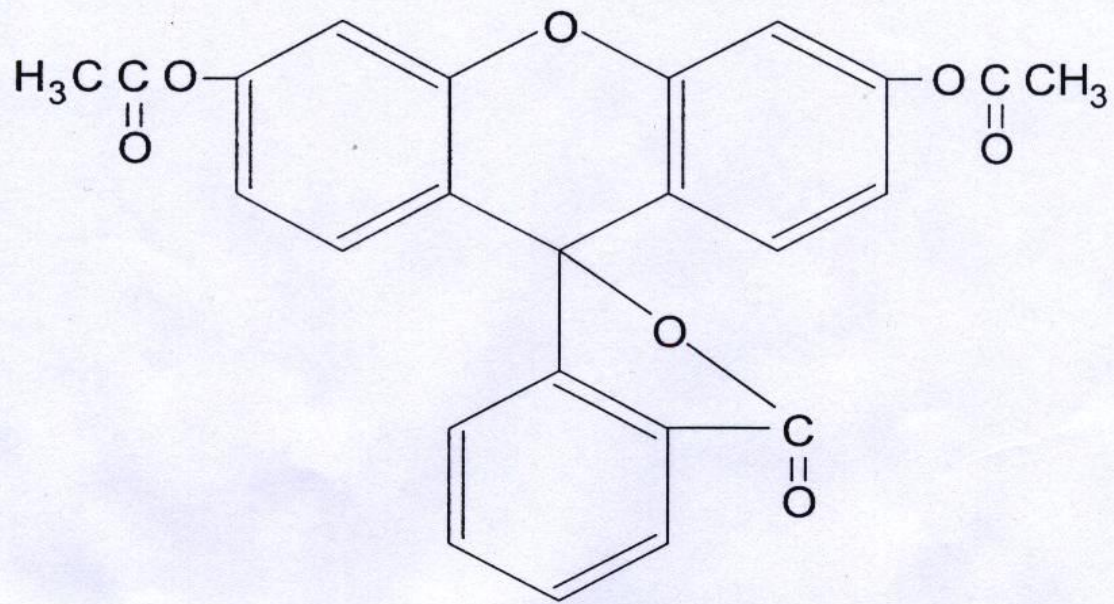

Fonte - Orsi, 1995.

FIGURA 6. Fórmula estrutural do 3, 6 diacetil fluoresceína

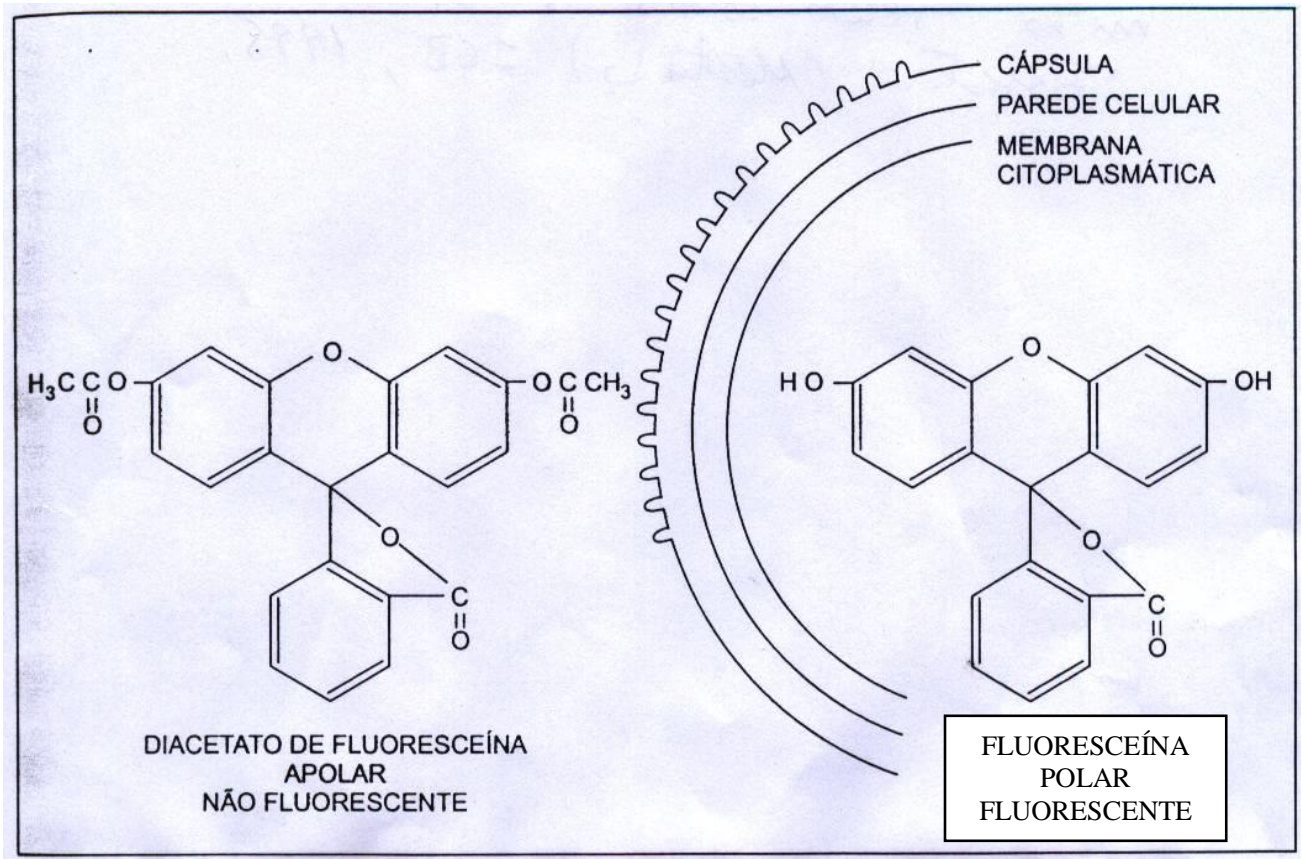

Fonte -Medzon \& Brady, 1969.

FIGURA 7. Mecanismo para reação fluorocromática de células vivas 
Outro corante fluorescente, o Brometo de Etídio (FIG. 8), penetra vagarosamente em células íntegras e rapidamente em células injuriadas originando uma fluorescência vermelho brilhante (Lopes, 2002).

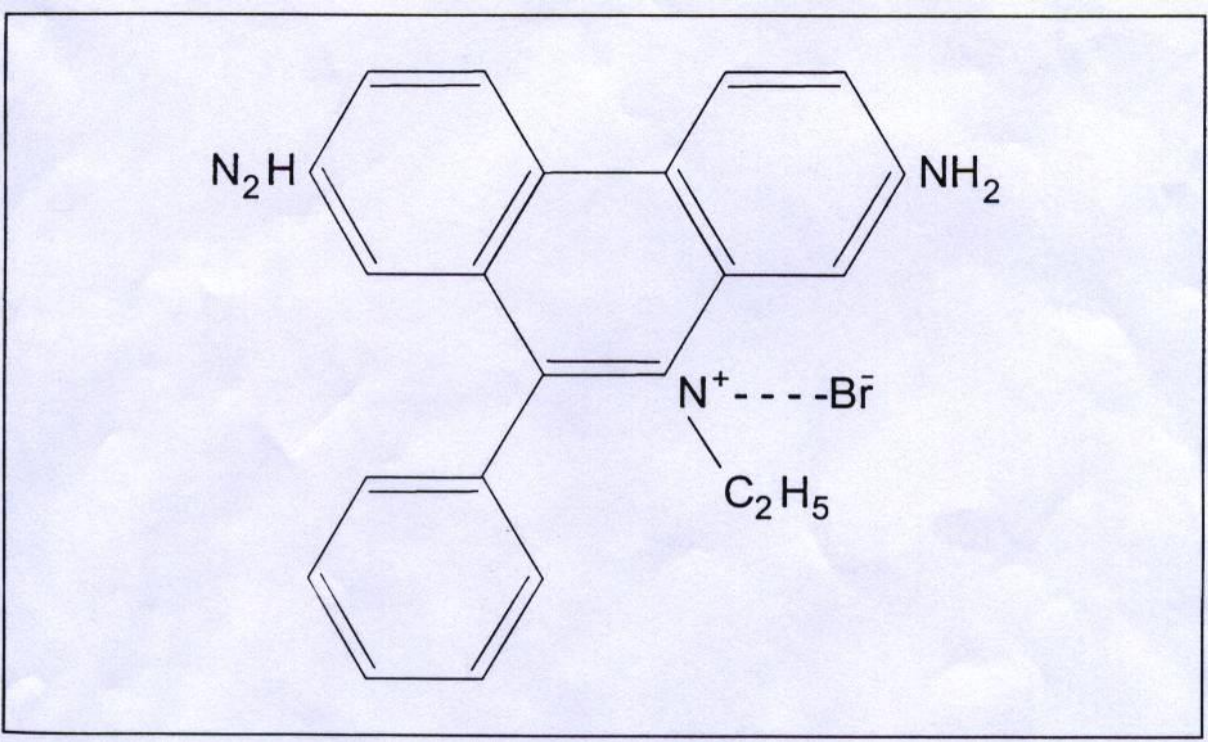

Fonte- Orsi, 1995.

FIGURA 8. Fórmula estrutural do brometo de 2,7 diamino 9 fenil, 10 etil fenantridina

O BE (brometo de 2,7 diamino 9 fenil, 10 etil fenantridina) possui a propriedade de penetrar rapidamente nas células danificadas, pois se liga ao DNA por intercalação, formando um complexo fluorescente com material nuclear, que visualizado ao microscópio de fluorescência, apresenta coloração avermelhada (Calich et al., 1978). Este corante é capaz de alterar o DNA mitocondrial e inibir sua síntese (Nass, 1972), mas não inibe a síntese de proteínas plasmáticas (Avadhani et al., 1975). 
Takasugi (1971), utilizou o DF em teste citotóxico empregando, concomitantemente, outro composto fluorescente, o BE, que foi utilizado por Edidin (1970), como contracorante nos estudos de viabilidade de células de mamíferos. A combinação de ambas as substâncias fluorescentes (DF-BE) foi utilizada para determinar a viabilidade de micobactérias em cultivo, biópsia de tecido e de células fúngicas em cultivo, salientando-se a sensibilidade e rapidez de execução desta técnica (Corrêa et al., 1990).

Rodrigues (2000), em seu estudo com três gêneros de dermatófitos, observou que as células não viáveis de dermatófitos coradas pelo BE apresentaram padrão uniforme de coloração (tonalidade vermelha clara e brilhante). Este fato também foi observado por outros autores estudando outros gêneros fúngicos (Calich et al., 1978; Corrêa et al., 1991). Em relação às células fúngicas viáveis, coradas pelo DF, estas exibiram áreas de intensa fluorescência em tonalidade Amarelo-esverdeada brilhante (Padrão de fluorescência PF1) e células com coloração esverdeada com fraca intensidade fluorescente (Padrão de fluorescência PF2) uniformemente distribuída. 


\section{4 - MATERIAIS E MÉTODOS}

\section{1- Amostras e milho}

Foram utilizadas 20 amostras de grãos de milho, contendo 200 gramas cada, (híbrido Pioneer 3041) cultivado na Faculdade de Medicina Veterinária da USP, "Campus" de Pirassununga. As amostras de milho, armazenadas desde abril de 2002, foram pesadas e acondicionadas em sacos plásticos individuais e envoltos em sacos de papel vedados com fita crepe.

\section{2- Irradiação}

As amostras foram irradiadas com a dose de $20 \mathrm{kGy}$ no Instituto de Pesquisas Energéticas e Nucleares (IPEN - CNEN/SP) - Fonte GammaCell de Cobalto 60, com taxa de dose variando entre $4,74 \mathrm{kGy} / \mathrm{h}$ a $4,84 \mathrm{kGy} / \mathrm{h}$, com a finalidade de se eliminar os microrganismos contaminantes presentes no milho (FIG.9). Após esta etapa, 5 amostras foram destinadas ao experimento para o controle ( $0 \mathrm{kGy}), 2 ; 5$ e $10 \mathrm{kGy}$, respectivamente. 


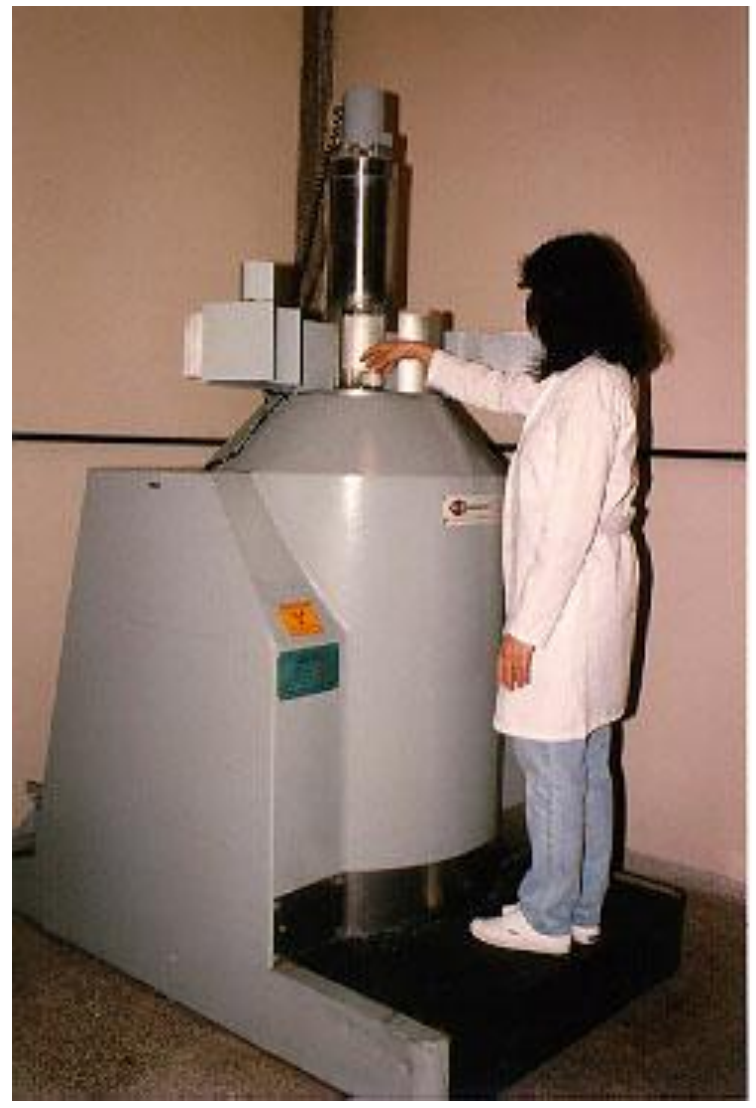

FIGURA 9. Foto da Fonte de Cobalto 60 (GammaCell 220 AECL) do Instituto de Pesquisas Energéticas e Nucleares - IPEN/CNEN.

\section{3 - - Ajuste de atividade de água $(A a)$ e Umidade Relativa $(U R)$}

As amostras, irradiadas previamente com a dose de $20 \mathrm{kGy}$, foram acondicionadas em recipiente de vidro, umedecidas com $35 \mathrm{ml}$ de água destilada estéril e inoculadas com A. flavus. Em seguida, foram colocadas em container plástico vedado, contendo recipiente com $200 \mathrm{ml}$ de solução salina saturada de Sulfato de Potássio Anidro a $30 \%\left(\mathrm{~K}_{2} \mathrm{SO}_{4}\right)$, a fim de se manter a 
umidade relativa de 97,5\% (Winston \& Bates, 1960). O container (FIG. 10) foi mantido em estufa à temperatura de $25{ }^{\circ} \mathrm{C}$ (FIG. 11), por 15 dias. Após o período de incubação, as amostras, exceto aquelas do grupo controle, foram irradiadas com de 2; 5 e $10 \mathrm{kGy}$.

\section{4 - Inoculação das amostras de milho com suspensão de Aspergillus flavus}

As amostras de milho foram inoculadas com suspensão da cepa de A. flavus produtora de aflatoxinas, proveniente do IMI (International Mycologi Institute). A suspensão de esporos foi preparada em frascos contendo solução Tampão Fosfato (PBS), pH 7,2 e Tween 80. A contagem foi efetuada em câmara de Neubauer e o número de esporos foi ajustado para $1 \times 10^{6}$ esporos /ml. Volume de $2 \mathrm{ml}$ da suspensão foi adicionado a cada amostra de 200 gramas de milho.

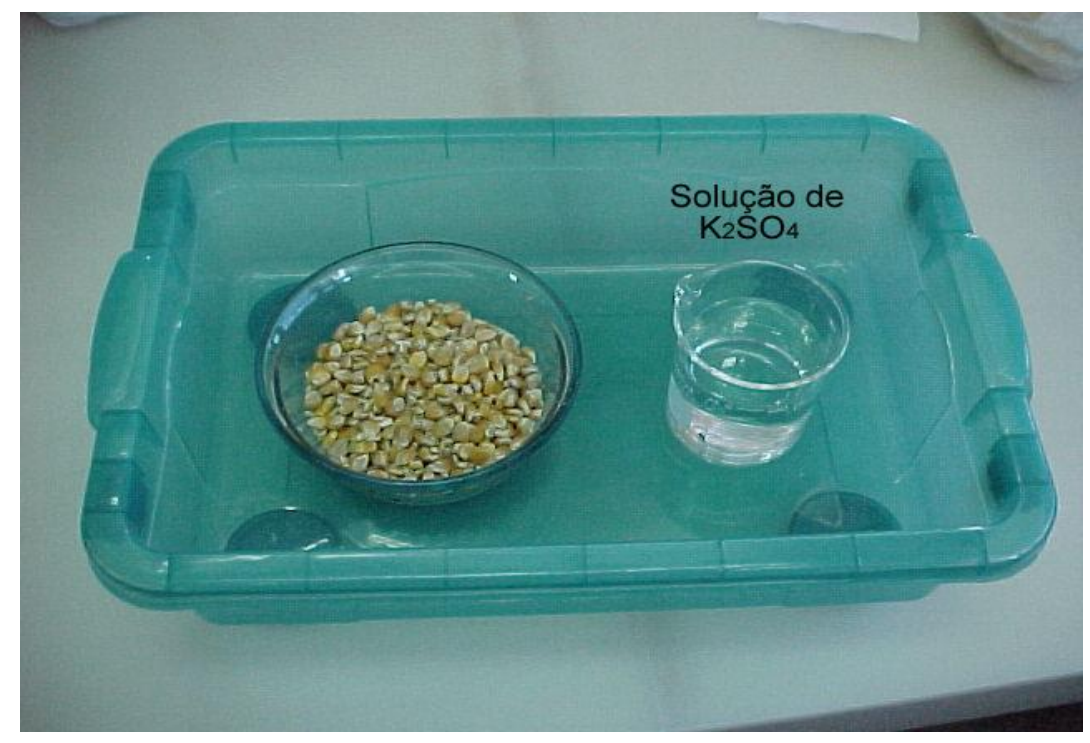

FIGURA 10. Container com milho e solução $\mathrm{K}_{2} \mathrm{SO}_{4}$ 


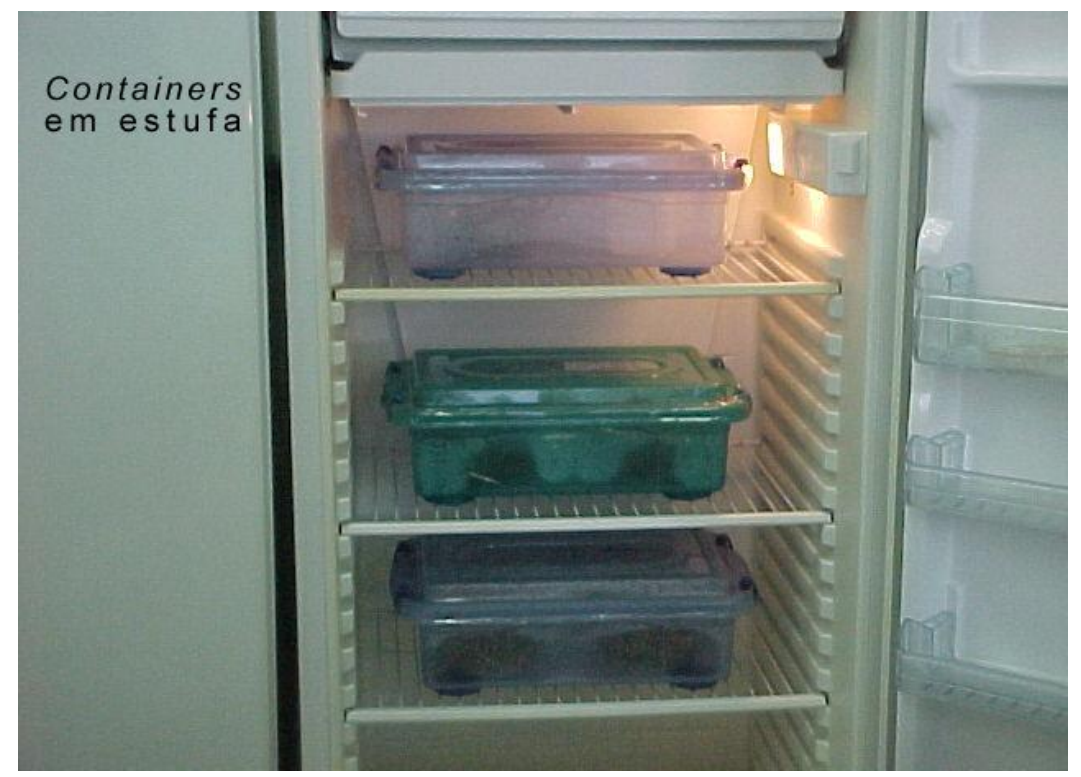

FIGURA 11. Estufa e containers

\section{5- Isolamento da microbiota fúngica das amostras}

Após o período de incubação, $10 \mathrm{~g}$ de cada amostra foram colocadas em frascos de vidro contendo $90 \mathrm{ml}$ de água destilada estéril, agitadas por 30 minutos e repassados $1 \mathrm{ml} \mathrm{em}$ diluições seriadas contidas em tubos de ensaio estéreis de $10^{-1}$ a $10^{-6}$. Para cada diluição, duas placas de Petri contendo agar AFPA (OXOID) foram semeadas com 0,1 ml de suspensão, distribuída pela superfície do meio e, posteriormente, incubadas por 6 dias a $25{ }^{\circ} \mathrm{C}$. A contagem foi determinada por UFC/g (Pitt et al., 1983). Colônias de diferentes tipos morfológicos foram isoladas em agar Sabouraud dextrose e submetidas à técnica de microcultivo (Riddell, 1950). Os fungos foram classificados até gênero, entretanto aqueles pertencentes do gênero Aspergillus foram classificados, até espécie, de acordo com os seguintes compêndios: Raper \& Fennell, 1965; Arx, 1974. 


\section{6 - Análise de Aflatoxina}

A extração, purificação e confirmação das aflatoxinas nas amostras de milho foram determinadas seguindo-se a metodologia preconizada por Soares \& Rodriguez-Amaya (1989). A quantificação foi realizada por fotodensitômetro marca Shimadzu, modelo CS $9000 \mathrm{com}$ lâmpada de xenônio e $\lambda$ de $366 \mathrm{~nm}$. O limite de detecção da técnica é de $2 \mu \mathrm{g} / \mathrm{kg}$.

\section{7 - Determinação da Atividade de água $(A a)$}

Os valores de $A a$ das amostras foram obtidos utilizando-se equipamento AQUALAB CX2, da Decagon Devices Inc (FIG.12).

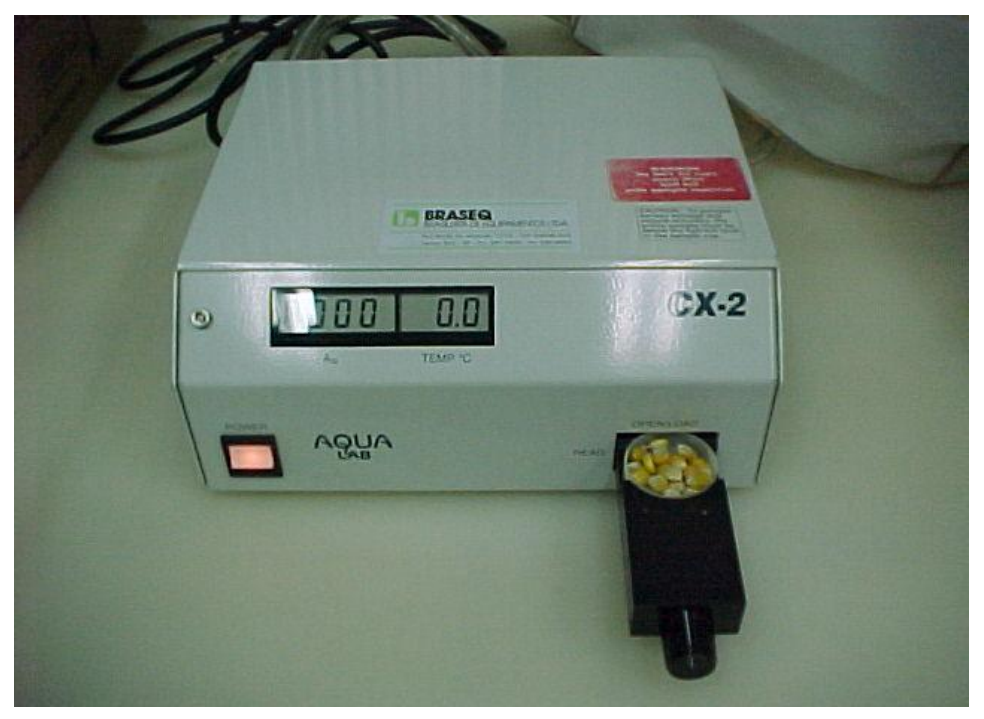

FIGURA 12 . Equipamento AQUALAB CX-2 


\section{8 - PCR}

A extração de DNA de A. flavus foi realizada segundo o protocolo do Kit DNeasy Plant Mini Kit marca Qiagen. Os primers utilizados, bem como o protocolo de amplificação, foram elaborados de acordo com Färber et al. (1997).

\section{a) Primers :}

- nor-1. 5' - ACCGCTACGCCGGCACTCTCGGCAC-3'

- nor-2. 5'- GTTGGCCGCCAGCTTCGACACTCCG-3'

b) O padrão de peso molecular:

Padrão 1 Kb DNA Ladder, obtido da Life Technologies (Patente U.S. N N 4.403 036).

c) Composição e quantidade de reagentes do mix:

TABELA 7. Composição dos reagentes para análise de PCR

\begin{tabular}{cc}
\hline Reagentes & Quantidade em $\boldsymbol{\mu l}$ \\
\hline Solução de DNA & 5 \\
Água bidestilada & 11,3 \\
Buffer com $\mathrm{MgCl}_{2}$ & 2,5 \\
Primer 1 & 1 \\
Primer 2 & 1 \\
DNTP & 4 \\
Taq- Polimerase & 0,2 \\
\hline
\end{tabular}

d) Programa Termociclador Gene Amp PCR System 9700, marca Biosystems (FIG. 13):

Desnaturação inicial $-95^{\circ} \mathrm{C}$ por 5 min

Amplificação $\rightarrow 30$ ciclos $\rightarrow$

Desnaturação $\rightarrow 95^{\circ} \mathrm{C}-1$ min

Anelamento $\rightarrow 62{ }^{\circ} \mathrm{C}-2 \mathrm{~min}$

Extensão $\rightarrow 72{ }^{\circ} \mathrm{C}-4$ min.

Extensão final - $72{ }^{\circ} \mathrm{C}$ por 7 min

Estabilização e parada de reação $-4^{\circ} \mathrm{C}$ 


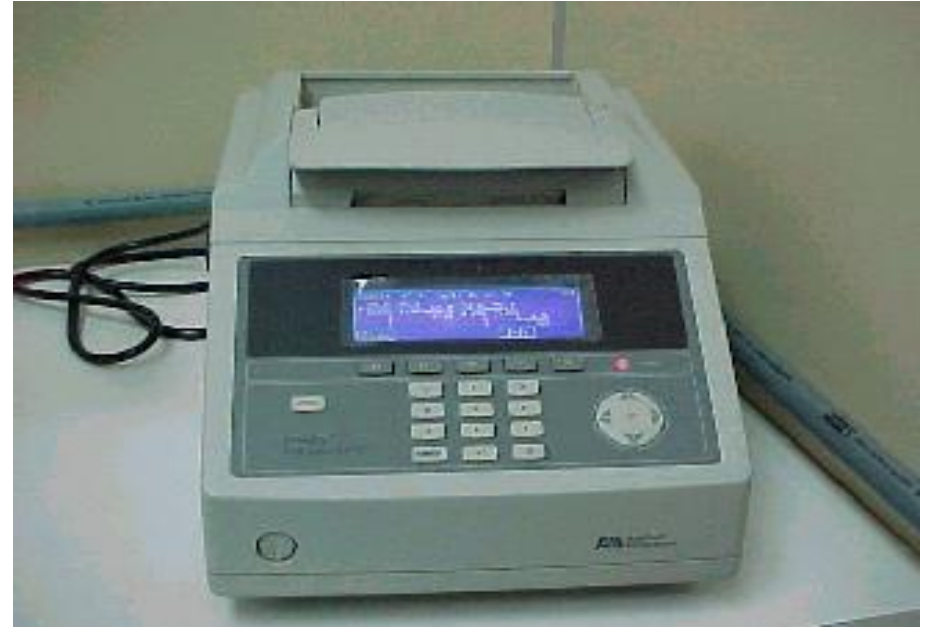

FIGURA 13. Termociclador Gene Amp PCR 9700

\section{e) Eletroforese:}

O gel de agarose foi preparado na concentração de $1,2 \%$ e a este foi adicionado $1 \mu 1$ de brometo de etídio. Cada uma das amostras e controles receberam $4 \mu \mathrm{l}$ de azul de bromofenol. A corrida foi realizada em cuba de eletroforese a $100 \mathrm{~V}$ em 1 hora (FIG.14). A disposição das amostras nos poços foi a seguinte: padrão de peso molecular 1 KB DNA Ladder $(8 \mu \mathrm{l})$, amostras $(10 \mu \mathrm{l}$ cada), controle negativo $(10 \mu \mathrm{l}$ de mix + água destilada) e controle positivo (10 $\mu \mathrm{l}$ de amostra com DNA de A. flavus). Finalizada a corrida, a imagem digital do gel foi registrada por sistema de fotodocumentação. 


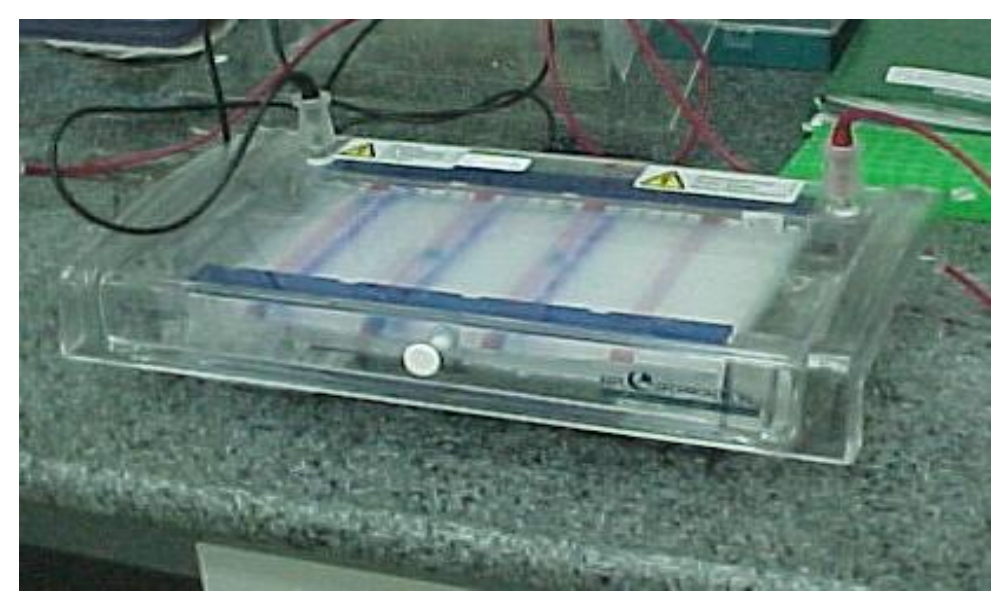

FIGURA 14. Cuba de eletroforese

\section{9 - Teste de viabilidade com corantes fluorescentes (DF-BE)}

Utilizou-se solução estoque de diacetato de fluoresceína (3,6 diacetil fluoresceína Sigma Chemical - USA), com uma concentração final de $5 \mathrm{mg} / \mathrm{ml}$ de acetona e mantida a temperatura de $-20{ }^{\circ} \mathrm{C}$. A solução estoque de brometo de etídio (2,7 - diamino-10-etil-9 fenil-fenantridina Sigma Chemical - USA), foi obtida em concentração de $1000 \mu \mathrm{g} / \mathrm{ml}$ de solução tampão de fosfatos (PBS) pH 7,4 e estocada a $-20{ }^{\circ} \mathrm{C}$. Diluiu-se a solução de diacetato de fluoresceína $2500 \mathrm{X}$ e a de brometo de etídio $20 \mathrm{X}$, ambas em PBS. Em seguida, foi tomado volumes iguais das soluções diluídas. De cada amostra de milho inoculada, uma alíquota de $1 \mathrm{~g}$ foi colocada em tubo de ensaio e acrescentado $1 \mathrm{ml}$ de água destilada estéril. Desta solução, alíquota 0,1 ml foi transferida para um novo tubo de ensaio e adicionadas partes iguais de DF e BE (0,1 ml). A mistura assim obtida foi incubada durante de 30 minutos a $25^{\circ} \mathrm{C}$. Em seguida, 1 gota da mistura foi colocada entre lâmina e lamínula e examinada em microscópio de fluorescência (FIG.15). 


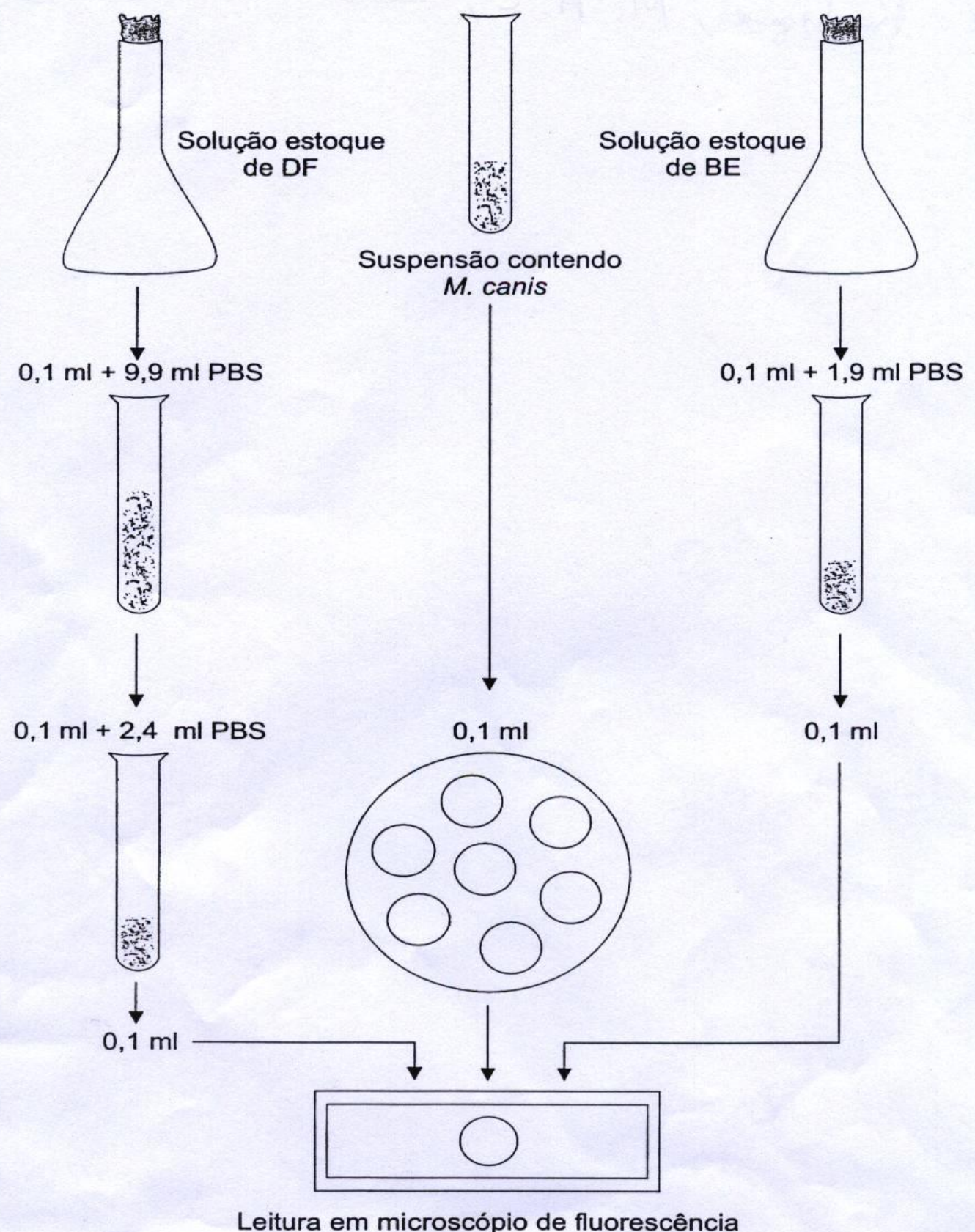

Fonte - Rodrigues, 2000.

FIGURA 15. Fluxograma de preparação do teste de viabilidade com os corantes fluorescentes diacetato de fluoresceína e brometo de etídio. 


\section{5- DELINEAMENTO EXPERIMENTAL}

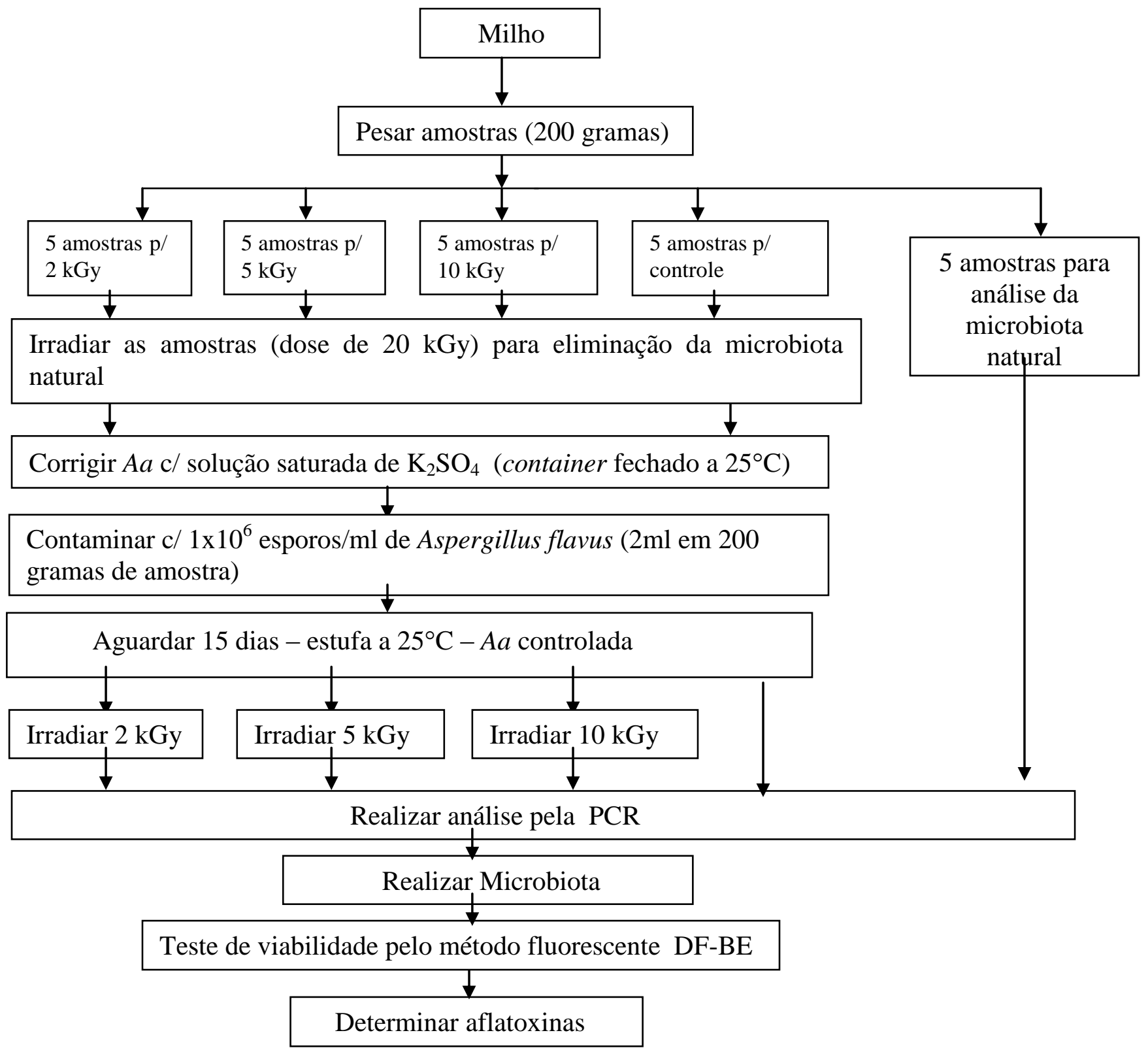

FIGURA 16. Representação esquemática das etapas do experimento 


\section{6-RESULTADOS E DISCUSSÃO}

\section{1- Análise prévia do milho utilizado no experimento (não irradiado e não inoculado)}

\subsection{1- Pesquisa da microbiota fúngica, $A a$ e determinação de aflatoxinas}

Observou-se a presença de fungos em todas amostras, principalmente dos gêneros Aspergillus, Penicillium e Fusarium, considerados como aqueles mais importantes do ponto de vista toxigênico. As espécies do gênero Fusarium foram as mais frequientes, com percentuais variando de 8,33\% a 94,81\%. O Número de Unidades Formadoras de Colônias por grama (UFC) variou de 0,7 a 7,1 x $10^{4}$. Dentro do gênero Aspergillus, A. flavus foi isolado em quatro amostras com freqüência variando de 2,07\% a 27,77\% (TAB. 9). Os níveis de $A a$ das amostras variaram de 0,73 a 0,77 (TABELA 8). Análises micotoxicológicas das amostras de milho não revelaram a presença de aflatoxinas.

Diversos autores relatam a predominância do gênero Fusarium em grãos de cereais. Abbas et al. (1988), analisando amostras de grãos de milho provenientes de 32 campos produtores em Minnesota (E.U.A.), isolaram, em ordem decrescente de freqüência as seguintes espécies do gênero Fusarium: F. graminearum (30\%), F. subglutinans (23\%), F. moliniforme (20\%), F. oxysporum (14\%) e F. proliferatum (12\%). Meirelles et al. (1994), analisando 38 amostras de grãos de milho envolvidos com surtos de leucoencefalomalácia eqüina - LEME, encontraram 97,4\% de contaminação por Fusarium spp., 57,9\% por Penicillium spp. e 36,8\% por Aspergillus spp. Dentro do gênero Fusarium, a espécie F. moniliforme (82\%) foi a mais prevalente. 
Segundo Almeida et al. (2002), as análises microbiológicas de 57 amostras de grãos de milho colhidas em diferentes estágios de maturidade nas regiões de Capão Bonito e Ribeirão Preto, revelaram uma população fúngica (microbiota) constituída, predominantemente, por Fusarium moniliforme. Os dados obtidos em nossa investigação vem ao encontro de outras publicações que apontam o gênero Fusarium como o fungo filamentoso de maior freqüência em grãos de milho recém-colhido e armazenado provenientes do Brasil. Orsi et al. (2000), estudando 195 amostras de três hídridos de milho recém-colhido e armazenado, provenientes de Ribeirão Preto, Estado de São Paulo, relacionaram a influência dos fatores abióticos, na freqüência de isolamento da microbiota fúngica. As análises microbiológicas demonstraram que o gênero Fusarium foi o mais freqüente, seguido dos gêneros Penicillium e Aspergillus. Com relação ao gênero Fusarium, a espécie $F$. moniliforme foi a mais freqüente nos 3 hídridos, principalmente na faixa de 0,70 a 0,79 de $A a$.

TABELA 8. Níveis de $A a$ das amostras de milho não irradiadas.

\begin{tabular}{ccc}
\hline Amostras & $\boldsymbol{A a}$ & Temperatura $^{\circ} \mathbf{C}$ \\
\hline 1 & 0,77 & 27,6 \\
2 & 0,77 & 27,4 \\
3 & 0,74 & 27,4 \\
4 & 0,73 & 27,3 \\
5 & 0,74 & 27,4 \\
Média & $\mathbf{0 , 7 5}$ & $\mathbf{2 7 , 4}$ \\
\hline
\end{tabular}


Data: $04 / 07 / 03$

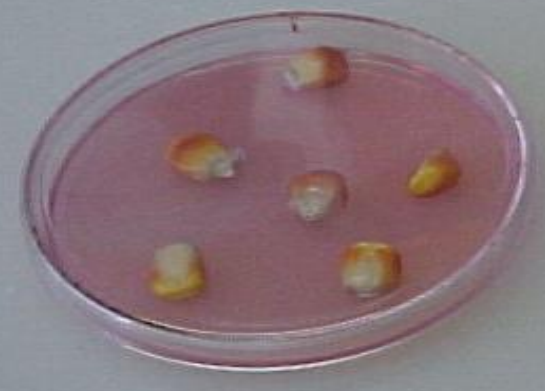

Irradiado c/ $20 \mathrm{kGy}$ e m $16 / 05 / 03$

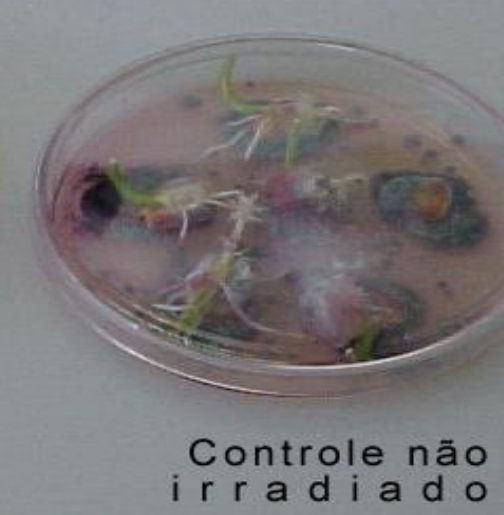

FIGURA 17. Amostra de milho irradiado com 20 kGy e controle (não irradiado). 
TABELA 9. Frequiência (\%) e número de Unidades Formadoras de Colônias por grama (UFC/g) em 5 amostras de grãos de milho não irradiados e não inoculados.

\begin{tabular}{|c|c|c|c|}
\hline Amostras & Fungo & Freqüência $(\%)$ & $* \mathbf{U F C} / \mathbf{g}$ \\
\hline \multirow[t]{5}{*}{1} & Cladosporium & $4,16 \%$ & \multirow[t]{5}{*}{$0,7 \times 10^{4}$} \\
\hline & Penicillium & $37,50 \%$ & \\
\hline & A. amstelodomi & $33,33 \%$ & \\
\hline & Fusarium & $8,33 \%$ & \\
\hline & A. ochraceus & $16,60 \%$ & \\
\hline \multirow[t]{4}{*}{2} & Fusarium & $27,77 \%$ & \multirow[t]{4}{*}{$0,8 \times 10^{4}$} \\
\hline & A. amstelodomi & $5,55 \%$ & \\
\hline & A. ochraceus & $38,88 \%$ & \\
\hline & A. flavus & $27,77 \%$ & \\
\hline \multirow[t]{4}{*}{3} & Fusarium & $94,81 \%$ & \multirow[t]{4}{*}{$6,6 \times 10^{4}$} \\
\hline & A. flavus & $2,07 \%$ & \\
\hline & A. ochraceus & $1,55 \%$ & \\
\hline & A. terreus & $1,55 \%$ & \\
\hline \multirow[t]{5}{*}{4} & Penicillium & $35,21 \%$ & \multirow[t]{5}{*}{$7,1 \times 10^{4}$} \\
\hline & A. ochraceus & $4,22 \%$ & \\
\hline & Fusarium & $57,04 \%$ & \\
\hline & A. flavus & $2,81 \%$ & \\
\hline & A. candidus & $0,70 \%$ & \\
\hline \multirow[t]{5}{*}{5} & A. candidus & $2,42 \%$ & \multirow[t]{5}{*}{$5,7 \times 10^{4}$} \\
\hline & Fusarium & $89,51 \%$ & \\
\hline & A. ochraceus & $0,80 \%$ & \\
\hline & A. restrictus & $0,80 \%$ & \\
\hline & A. flavus & $6,45 \%$ & \\
\hline
\end{tabular}

* Número de Unidades Formadoras de Colônias 


\subsection{2- Análise pelo método de PCR:}

Para monitorar o processo de detecção de DNA e a amplificação das sequiências, são necessários controles positivo e negativo. O controle positivo contem material com o DNA a ser amplificado pelos primers específicos, com a finalidade de checar a qualidade da preparação das amostras e da adequação dos parâmetros para a amplificação (escolha dos primers, temperatura de anelamento, tempo para cada etapa do PCR, número de ciclos para amplificação de DNA, etc). A falha na deteç̧ão do controle positivo significa que existem fatores inibitórios, quantidade insuficiente de DNA na amostra a ser analisada ou os parâmetros usados para o PCR não estão corretos. O controle negativo é utilizado para confirmar a existência de contaminação de DNA no laboratório. Se um sinal é produzido, significa que os procedimentos preventivos de contaminação de materiais e soluções da extração e amplificação falharam (Gachet et al., 1999). Para o controle negativo, em lugar de DNA, é colocado água Milli $Q$ autoclavada. 
A análise pelo PCR das amostras de grãos de milho não irradiado revelou a presença de banda intensa no controle positivo $(\mathrm{C}+)$, ausência de produto na corrida do gel correspondente ao controle negativo (C -) e uma fraca banda de DNA de Aspergillus flavus na linha la na corrida da Polimerase da marca Biotools (FIG. 18). Nas demais não houve formação de bandas evidentes, indicando pouca quantidade de DNA de A. flavus, uma vez que a banda do controle positivo foi fortemente detectado. Para a realização dos demais ensaios de amplificação, os parâmetros descritos em materiais e métodos foram mantidos (TAB. 7) e a polimerase de escolha foi a da marca Biotools.

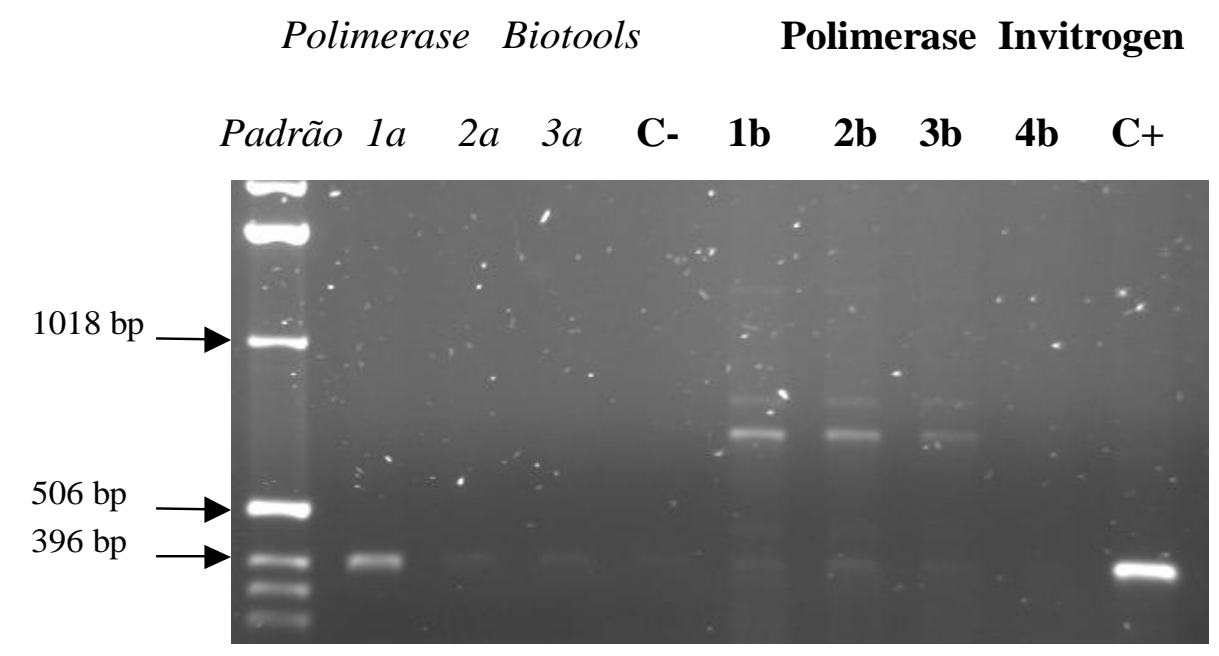

FIGURA 18. Gel de eletroforese (PCR) de DNA extraído de A. flavus das amostras 1, 2,3 e 4 do milho não irradiado. 


\subsection{Análise das amostras irradiadas com $2 ; 5$ e 10 kGy e controle (0 kGy).}

\subsection{1- Microbiota fúngica das amostras de milho do grupo controle (0 kGy) e irradiadas com 2; 5 e 10 kGy.}

A aplicação de doses entre 2 e 7 kGy de radiação de ${ }^{60}$ Cobalto, resulta em uma destruição considerável de microrganismos presentes nos alimentos, praticamente eliminando os patógenos (WHO, 1994). Outra constatação importante foi realizada por Saleh et al. (1996) e Abd El- Aal et al. (1997) que observaram os efeitos da radiação gama em fungos, aplicando doses entre 4 e 6 kGy, visando uma completa inibição do fungo em diferentes alimentos.

Aziz et al., (2002) estudaram os efeitos da radiação gama na microbiota fúngica de frutas armazenadas em temperatura de refrigeração (abaixo de $10{ }^{\circ} \mathrm{C}$ ). O número inicial de unidades formadoras de colônias por grama (UFC/g) nas frutas variou de $4,8 \times 10^{4}$ a $6,8 \times 10^{5}$ por grama. Quando as frutas foram irradiadas com dose de $1,5 \mathrm{kGy}$, a contagem total de fungos foi reduzida a $1,4 \times 10^{2}-2,5 \times 10^{3}$. Naquelas irradiadas com a dose de $3,5 \mathrm{kGy}$, a redução variou de $1,4 \times 10^{1}$ a $2,5 \times 10^{2}$ por grama.

Em nossa investigação, a radiação gama foi efetiva na prevenção do crescimento. $\mathrm{O}$ maior grau de contaminação (40 a $650 \times 10^{5} \mathrm{UFC/g}$ ) foi observado no grupo não irradiado (controle). Os demais grupos, irradiados com 2; 5 e $10 \mathrm{kGy}$, apresentaram diminuição significativa no número de UFC/g. Em algumas amostras do grupo irradiado com $5 \mathrm{kGy}$ (amostras 3 e 4) e $10 \mathrm{kGy}$ (amostras 1 e 4), não foi observado crescimento fúngico (TAB. 10). 
TABELA 10. Número de *UFC/g das amostras de milho do grupo controle e irradiadas com 2 , 5 e $10 \mathrm{kGy}$, incubadas a $25^{\circ} \mathrm{C}$, durante 6 dias.

\begin{tabular}{|c|c|c|c|c|}
\hline & Controle & 2 kGy & 5 kGy & 10 kGy \\
\hline Amostra 1 & $500 \times 10^{5}$ & $0,5 \times 10^{5}$ & $0,001 \times 10^{5}$ & 0 \\
\hline Amostra 2 & $40 \times 10^{5}$ & $0,05 \times 10^{5}$ & $0,001 \times 10^{5}$ & $0,0005 \times 10^{5}$ \\
\hline Amostra 3 & $600 \times 10^{5}$ & $1,5 \times 10^{5}$ & 0 & $0,002 \times 10^{5}$ \\
\hline Amostra 4 & $600 \times 10^{5}$ & $0,2 \times 10^{5}$ & 0 & 0 \\
\hline Amostra 5 & $650 \times 10^{5}$ & $0,03 \times 10^{5}$ & $0,001 \times 10^{5}$ & $0,001 \times 10^{5}$ \\
\hline Média & $478 \times 10^{5}$ & $0,456 \times 10^{5}$ & $0,0006 \times 10^{5}$ & $0,00070 \times 10^{5}$ \\
\hline D. P. & $250,8 \times 10^{5}$ & $0,613 \times 10^{5}$ & $0,0005 \times 10^{5}$ & $0,00084 \times 10^{5}$ \\
\hline I.C. $(95 \%)$ & $478,0 \pm 311,4$ & $0,456 \pm 0,761$ & $0,0006 \pm 0,0006$ & $\mathbf{0 , 0 0 0 7} \pm \mathbf{0 , 0 0 1 0}$ \\
\hline
\end{tabular}

- D. P. = Desvio Padrão

- Foram realizados testes de Student generalizado para várias amostras e teste de Tukey.

- I.C. = Intervalo de Confiança

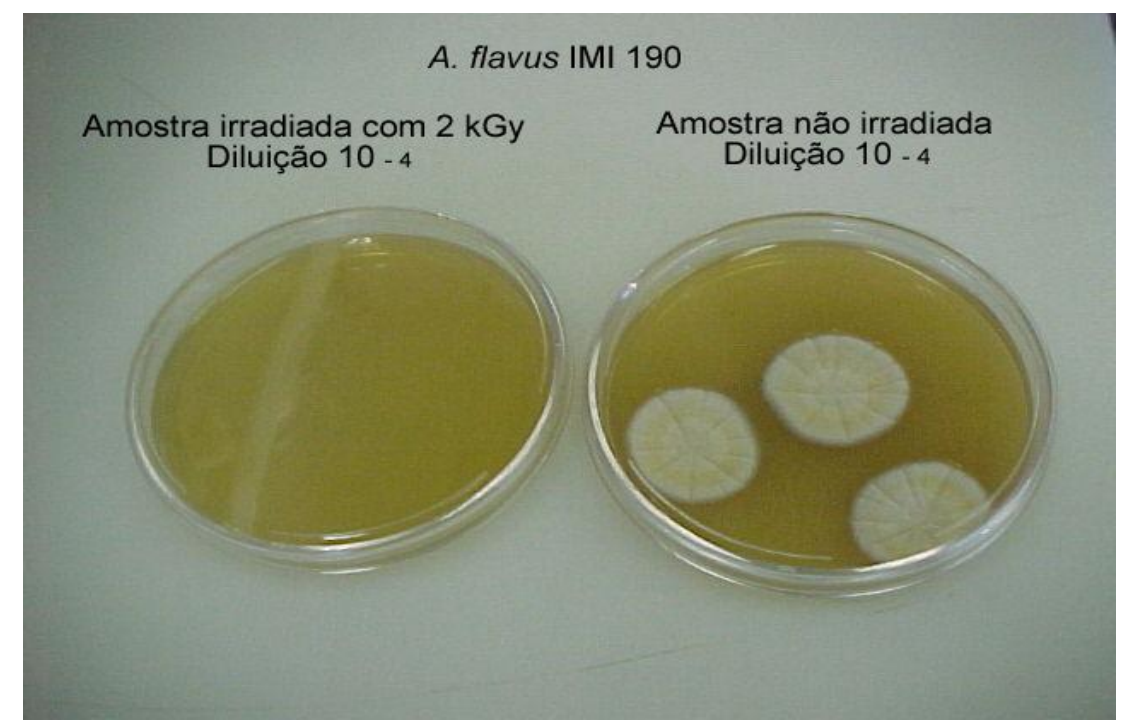

FIGURA 19. Cultura de A. flavus em meio AFPA das amostras irradiadas com $2 \mathrm{kGy}$ (sem formação de colônias) e não irradiada (com formação de colônias), ambas na diluição $10^{-4}$. 


\subsection{2 - Atividade de água (Aa) do controle e das amostras irradiadas com 2; 5 e $10 \mathrm{kGy}$}

Os níveis de Atividade de água dos grãos das amostras antes da incubação e após a irradiação com dose de $20 \mathrm{kGy}$, variaram de 0,55 a 0,65, nas diferentes amostras (TAB. 11). Após a irradiação com a dose de $20 \mathrm{kGy}$, para eliminação da microbiota natural, os valores de $A a$ sofreram uma redução em torno de 0,10 a 0,20, uma vez que a atividade de água média do milho no momento da aquisição, girava em torno de 0,75 (TAB. 8). Tal fato se deve ao efeito da radiólise da água disponível nas amostras, como efeito da radiação gama na dose de 20 kGy.

TABELA 11. Níveis de Atividade de água $(A a)$ das amostras de milho antes da incubação e após a irradiação com dose de $20 \mathrm{kGy}$.

\begin{tabular}{ccccc}
\hline Amostras & Controle & $\mathbf{2}$ kGy & $\mathbf{5}$ kGy & $\mathbf{1 0}$ kGy \\
\hline 1 & 0,56 & 0,65 & 0,60 & 0,66 \\
2 & 0,55 & 0,61 & 0,60 & 0,65 \\
3 & 0,53 & 0,60 & 0,59 & 0,63 \\
4 & 0,56 & 0,58 & 0,58 & 0,67 \\
5 & 0,58 & 0,60 & 0,62 & 0,66 \\
Média & $\mathbf{0 , 5 5}$ & $\mathbf{0 , 6 0}$ & $\mathbf{0 , 6 0}$ & $\mathbf{0 , 6 5}$ \\
\hline
\end{tabular}

Em tais condições, a germinação e crescimento não seriam observados, após a etapa de inoculação de esporos do fungo, caso o ajuste de $A a$ não fosse realizado, uma vez que a germinação e crescimento de $A$. flavus requerem $A a$ acima de 0,85 e temperatura mínima de 10 ${ }^{\circ} \mathrm{C}$ (Council For Agricultural Science And Technology, 2003). Após a incubação por 15 dias, os níveis médios de $A a$ das amostras atingiram valores entre 0,88 a 0,94 (TAB. 12), ideais para o desenvolvimento do estudo. 
TABELA 12. Valores de Atividade de Água $(A a)$ das amostras de milho, após 15 dias de incubação a $25^{\circ} \mathrm{c}$ em ambiente com Umidade Relativa de 97,5\%.

\begin{tabular}{ccccc}
\hline Amostras & Controle & $\mathbf{2}$ kGy & $\mathbf{5 ~ k G y}$ & $\mathbf{1 0} \mathbf{~ k G y}$ \\
\hline 1 & 0,92 & 0,91 & 0,90 & 0,96 \\
2 & 0,91 & 0,92 & 0,91 & 0,96 \\
3 & 0,93 & 0,89 & 0,87 & 0,92 \\
4 & 0,93 & 0,93 & 0,87 & 0,92 \\
5 & 0,94 & 0,92 & 0,87 & 0,96 \\
Média & $\mathbf{0 , 9 2 6}$ & $\mathbf{0 , 9 1 4}$ & $\mathbf{0 , 8 8 4}$ & $\mathbf{0 , 9 4 4}$ \\
D. P. & $\mathbf{0 , 0 1 1}$ & $\mathbf{0 , 0 1 5}$ & $\mathbf{0 , 0 1 9}$ & $\mathbf{0 , 0 2 2}$ \\
I.C. (95\%) & $\mathbf{0 , 9 2 6} \pm \mathbf{0 , 0 1 4}$ & $\mathbf{0 , 9 1 4} \pm \mathbf{0 , 0 1 9}$ & $\mathbf{0 , 8 8 4} \pm \mathbf{0 , 0 2 4}$ & $\mathbf{0 , 9 4 4} \pm \mathbf{0 , 0 2 7}$ \\
\hline
\end{tabular}

- D. P. = Desvio Padrão

- I.C. = Intervalo de Confiança

\subsection{3 - Determinação de Aflatoxinas nas amostras controle e irradiadas com doses de 2, 5 e 10 kGy:}

O uso de radiação gama para inativar aflatoxinas já foi investigado (Rustom, 1997) . A toxicidade de um alimento a base de amendoim, contaminado com $\mathrm{AFB}_{1}$, foi reduzida a $75 \%$ e 100\% após a irradiação com raios gama nas doses de 1 e 10 kGy, respectivamente (Temcharoen \& Thilly, 1982). A presença de água tem um importante papel na destruição de aflatoxina por energia gama, uma vez que a radiólise da água leva à formação radicais livres altamente reativos. Estes radicais podem atacar $\mathrm{AFB}_{1}$, no anel furano terminal, gerando produtos de baixa atividade biológica (Rustom, 1997). Patel et al. (1989) obtiveram, com a adição de $1 \mathrm{ml}$ de peróxido de hidrogênio a $5 \%$ em uma solução aquosa de $\mathrm{AFB}_{1}(50 \mu \mathrm{g} / \mathrm{ml})$, a degradação de 37 a $100 \%$ da toxina nas doses mais baixas (2 kGy). Os produtos finais da degradação não demonstraram qualquer atividade, no teste de mutagenicidade de Ames. O mesmo tratamento reduziu os níveis de $\mathrm{AFB}_{1}$ em sementes de amendoim em $73-80 \%$. 
Uma certa preocupação foi causada quando uma série de relatos indicando o aumento da produção de aflatoxinas em esporos de A. flavus ou A. parasiticus ou culturas derivadas de cada um destes esporos, foram irradiados. Contudo, os resultados não foram claros. No entanto, Ingram e Farkas (1977), revisando alguns destes primeiros estudos, concluíram que a irradiação propiciou a diminuição da produção de aflatoxinas, sem, contudo, ocorrer qualquer aumento nos níveis da toxina

Segundo alguns autores, os riscos de produção de aflatoxinas nos alimentos pós-irradiados não é maior dos que naqueles alimentos não irradiados e armazenados em condições normais. O aumento da produção de aflatoxina após a irradiação, verificado em condições laboratoriais, não são observadas na prática (Germano et al., 2001).

Várias publicações sugerem que fungos são sensíveis à radiação gama e que a produção de micotoxinas diminui após a irradiação de alimentos (Refai et al., 1996; Youssef et al., 1999). Neste sentido, Aziz et al.,(2002) demonstraram redução na concentração de $\mathrm{AFB}_{1}$ em ameixas e tâmaras irradiadas com a dose de $3,5 \mathrm{kGy}$ e estocadas em refrigeração durante 28 dias, em relação ao dia 0 (sem irradiação) (TAB. 13). 
TABELA 13. Detecção de micotoxinas em diferentes amostras de frutas não irradiadas e irradiadas (3,5 kGy) e estocadas em refrigeração por 28 dias.

\begin{tabular}{lccc}
\hline Amostras não irradiadas & Total de amostras & $\begin{array}{c}\text { Amostras } \\
\text { positivas }\end{array}$ & $\begin{array}{c}* * \text { Conc. média de } \\
\mathrm{AFB}_{1}(\mu \mathrm{g} / \mathrm{kg})\end{array}$ \\
$\begin{array}{l}\text { Ameixa } \\
\text { Tâmara }\end{array}$ & 10 & 2 & $380-500$ \\
& 4 & 4 & $380-500$ \\
$\begin{array}{l}\text { Amostras irradiadas } \\
\text { (3,5 kGy) }\end{array}$ & Total de amostras & Amostras & $* *$ Conc. média de \\
Ameixa & 10 & positivas & $\mathrm{AFB}_{1}(\mu \mathrm{g} / \mathrm{kg})$ \\
Tâmara & 4 & 1 & 20 \\
\hline
\end{tabular}

Fonte: Adaptada de Aziz et al., 2002.

* Limite não detectável

** Concentração média de $\mathrm{AFB}_{1}$

*** Limite de detecção de $\mathrm{AFB}_{1}=0,1 \mu \mathrm{g} / \mathrm{kg}$

Em nosso estudo, observamos que a inativação das aflatoxinas $\mathrm{AFB}_{1}$ e $\mathrm{AFB}_{2}$ foi mais eficaz nas doses de $2 \mathrm{kGy}$, do que nas doses de $5 \mathrm{kGy}$. Isto se explica uma vez que as amostras irradiadas com dose de $2 \mathrm{kGy}$ apresentaram $A a$ mais elevada (média de 0,91 ), em relação às irradiadas com dose de $5 \mathrm{kGy}$ (Aa média de 0,88) (TAB. 12).

A não detecção de aflatoxinas nas amostras de $10 \mathrm{kGy}$ comprova que tal dose foi efetiva na completa degradação destas toxinas, associada a $A a$ elevada das amostras (com média de 0,94). Também é possível observar que a $\mathrm{AFB}_{2}$ é mais radiosensível do que $\mathrm{AFB}_{1}$, sendo diminuída em torno de 44 vezes na dose de 2 kGy e 17 vezes na dose de $5 \mathrm{kGy}$, já com relação aos níveis de $\mathrm{AFB}_{1}$, estes diminuíram em torno de 3 vezes para a dose de $2 \mathrm{kGy}$ e 2 vezes para a dose de 5 kGy (FIG. 20 e 21). 
Os níveis de $\mathrm{AFB}_{1}$ detectados nas amostras do grupo controle variaram de 1844,4 a 2597,2 $\mu \mathrm{g} / \mathrm{kg}$ Nas amostras dos grupos irradiados os níveis variaram de 398,3 a 1187,4 $\mu \mathrm{g} / \mathrm{kg}$ $(2 \mathrm{kGy}) ; 1046,8$ a $1552,0 \mu \mathrm{g} / \mathrm{kg}$ (5kGy). Nas amostras irradiadas com 10 kGy não foi detectada a presença de aflatoxina $\mathrm{B}_{1}$ (TAB. 14 e FIG.20).

Em relação a $\mathrm{AFB}_{2}$, os níveis detectados no grupo controle variaram de 481,1 a 778,2 $\mu \mathrm{g}$ /kg. Os níveis de $\mathrm{AFB}_{2}$ nas amostras irradiadas variaram de 5,7 a 27,2 $\mu \mathrm{g} / \mathrm{kg}(2 \mathrm{kGy}) ; 15,1$ a $97,9 \mu \mathrm{g} / \mathrm{kg}$ (5kGy). Por outro lado, nas amostras irradiadas com $10 \mathrm{kGy}$, a presença de $\mathrm{AFB}_{2}$ não foi detectada (TAB. 15 e FIG. 21). 


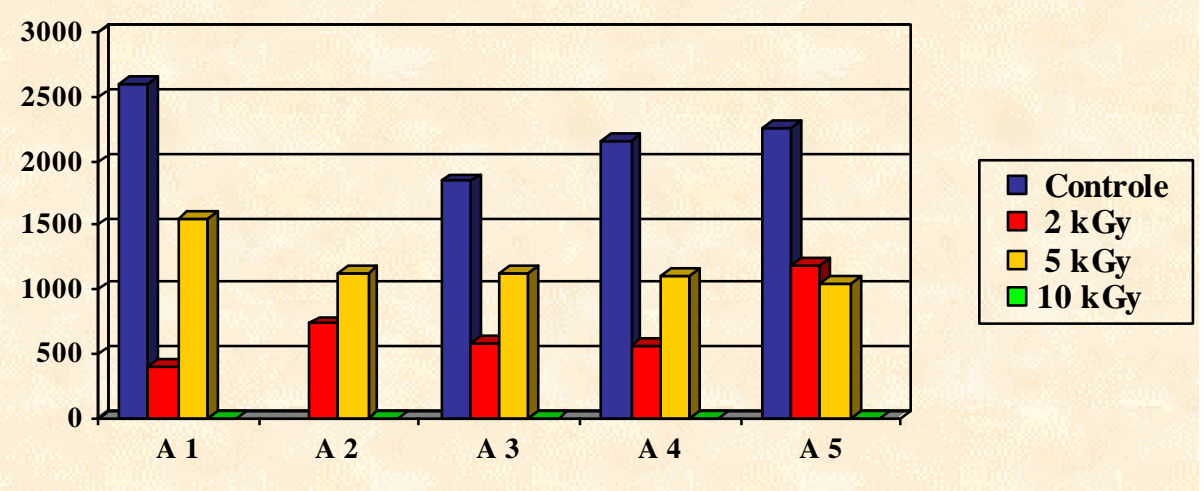

FIGURA 20 - Quantificação de $\mathrm{AFB}_{1}$ nas amostras do controle, 2; 5 e 10 kGy, em $\mu \mathrm{g} / \mathrm{kg}(\mathrm{ppb})$.

TABELA 14. Quantificação de $\mathrm{AFB}_{1}$ do controle e amostras irradiadas com 2, 5 e $10 \mathrm{kGy}$ em $\mu \mathrm{g} / \mathrm{kg}$.

\begin{tabular}{ccccc}
\hline Amostras & $\begin{array}{c}\text { Controle } \\
(\boldsymbol{\mu g} / \mathbf{k g})\end{array}$ & $\begin{array}{c}\mathbf{2} \mathbf{~ k G y} \\
(\boldsymbol{\mu g} / \mathbf{k g})\end{array}$ & $\begin{array}{c}\mathbf{5} \mathbf{~ k G y} \\
(\boldsymbol{\mu g} / \mathbf{k g})\end{array}$ & $\begin{array}{c}\mathbf{1 0} \mathbf{~ k G y} \\
(\boldsymbol{\mu g} / \mathbf{k g})\end{array}$ \\
\hline 1 & 2597,2 & 398,3 & 1552,0 & ND * \\
2 & ND $*$ & 729,5 & 1120,5 & ND * \\
3 & 1844,4 & 571,7 & 1121,1 & ND * \\
4 & 2159,4 & 556,5 & 1096,0 & ND * \\
5 & 2258,5 & 1187,4 & 1046,8 & ND * \\
Média & $\mathbf{2 2 1 4 , 8 8}$ & $\mathbf{6 8 8 , 6 8}$ & $\mathbf{1 1 8 7 , 2 8}$ & ND * \\
D. P. & $\mathbf{3 1 0 , 0 6}$ & $\mathbf{3 0 2 , 4 3}$ & $\mathbf{2 0 6 , 1 1}$ & - \\
I.C. $(\mathbf{9 5 \%})$ & $\mathbf{2 2 1 4 , 8 8} \pm \mathbf{4 9 3 , 4}$ & $\mathbf{6 8 8 , 6 8} \pm \mathbf{3 7 5 , 5}$ & $\mathbf{1 1 8 7 , 2 8} \pm \mathbf{2 5 5 , 9}$ & - \\
\hline
\end{tabular}

- Nota : ND = Não Detectável

- D. P. = Desvio Padrão

- I.C. = Intervalo de Confiança 


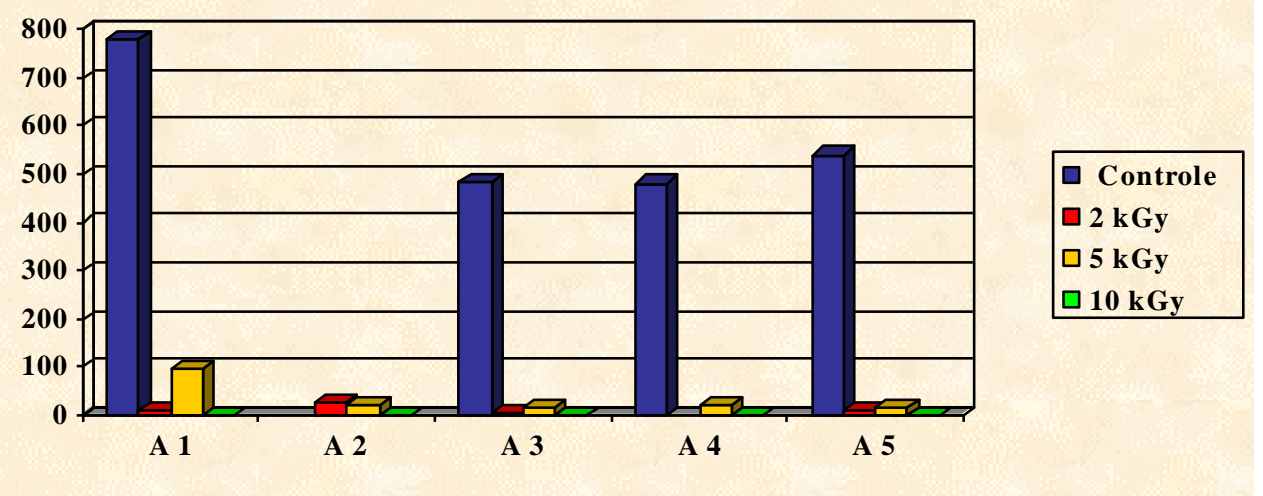

FIGURA 21. Quantificação de $\mathrm{AFB}_{2}$ nas amostras do controle, 2, 5 e $10 \mathrm{kGy}$, em $\mu \mathrm{g} / \mathrm{kg}(\mathrm{ppb})$.

TABELA 15. Quantificação de Aflatoxina $\mathrm{B}_{2}$ do controle e amostras irradiadas com 2,5 e $10 \mathrm{kGy}$ em $\mu \mathrm{g} / \mathrm{kg}$.

\begin{tabular}{|c|c|c|c|c|}
\hline Amostras & $\begin{array}{c}\text { Controle } \\
(\mu \mathrm{g} / \mathrm{kg})\end{array}$ & $\begin{array}{c}2 \mathrm{kGy} \\
(\mu \mathrm{g} / \mathrm{kg})\end{array}$ & $\begin{array}{c}5 \mathrm{kGg} \\
(\mu \mathrm{g} / \mathrm{kg})\end{array}$ & $\begin{array}{l}10 \mathrm{kGy} \\
(\mu \mathrm{g} / \mathrm{kg})\end{array}$ \\
\hline 1 & 778,2 & 11,3 & 97,9 & ND * \\
\hline 2 & $\mathrm{ND} *$ & 27,2 & 20,5 & $\mathrm{ND} *$ \\
\hline 3 & 485,0 & 5,7 & 17,1 & $\mathrm{ND} *$ \\
\hline 4 & 481,1 & $\mathrm{ND} *$ & 19,8 & $\mathrm{ND} *$ \\
\hline 5 & 540,1 & 9,7 & 15,1 & $\mathrm{ND} *$ \\
\hline Média & 571,10 & 13,48 & 34,08 & ND * \\
\hline D. $P$. & 140,67 & 9,45 & 35,74 & - \\
\hline I.C. $(95 \%)$ & $571,10 \pm 223,8$ & $13,48 \pm 11,73$ & $34,08 \pm 44,38$ & - \\
\hline
\end{tabular}

- ND = Não Detectável

- D. P. = Desvio Padrão

- I.C. = Intervalo de Confiança 


\subsection{4 - Análise pelo método de PCR das amostras de milho do grupo controle e das amostras irradiadas com as doses de 2,5 e $10 \mathrm{kGy}$.}

O emprego da técnica de PCR com finalidade diagnóstica, freqüentemente gera resultados falso negativos, devido à presença de compostos interferentes presentes no substrato (Färber, 1997). Neste sentido, Rossen, et al. (1992) descreveu que a técnica de PCR é sensível nas amostras de alimentos complexos que contêm quantidades altas de gordura, proteínas e carboidratos.

Rowe e Towner (1994) demonstraram que contaminação bacteriana total pode ser ainda detectada por técnicas de hibridização em amostras de alimentos irradiados contendo bactérias não viáveis. Técnica qualitativa de PCR, no entanto, não distingue células viáveis de células mortas de microrganismos. O PCR é uma técnica rápida e sensível para a amplificação específica de um segmento particular de DNA (Zhou et al., 2000).

Técnicas de hibridização de DNA têm sido desenvolvidas para detectar a contaminação bacteriana em alimentos (Hill, 1991). Dúvidas surgiram a respeito da possibilidade de que a irradiação provocasse mudanças nas estruturas moleculares e no DNA de microrganismos patogênicos, a ponto de não permitir a correta detecção, ou seja, que o processo poderia ser usado para mascarar condições sem higiene na produção e manipulação de alimentos, “erradicando" a contaminação bacteriana detectável (Diehl,1995). 
A probabilidade $(\mathrm{X})$ de uma molécula com peso molecular $\mathbf{M}$ sofrer mudanças com a irradiação é dada por (Brynjolfsson, 1981):

$$
\mathrm{X}=10^{-7} \text {. G. M. D }
$$

Onde $\mathbf{G}=$ o número de mudanças por $100 \mathrm{eV}$ de energia absorvida

$\mathbf{D}=\mathrm{a}$ dose em $\mathrm{kGy}$

$\mathrm{O}$ valor de $\mathrm{G}$ está usualmente abaixo de 4 quando sistemas aquosos são irradiados. Se a água (M=18) é irradiada com uma dose (D) de 10 kGy, então;

$$
\mathrm{X}=10^{-7} \cdot 4 \cdot 18 \cdot 10=7,2 \cdot 10^{-5}
$$

Significa que 7,2 de cada 100000 moléculas de água sofreram mudanças. Se o DNA com um peso molecular de $\mathrm{M}=10^{9}$ é irradiado, têm - se $\mathrm{X}=4000$, o que significa cada molécula de DNA sofreu mudanças em 4000 vezes. A maior parte destas mudanças pode não ser letal, mas a quebra das fitas duplas freqüentemente é. $\mathrm{O}$ valor $\mathrm{G}$ para quebra das duplas fitas gira em torno de 0,07. Este DNA poderia então ter recebido 70 quebras na dupla fita.

$$
\mathrm{X}=10^{-7} \cdot 0,07 \cdot 10^{9} \cdot 10=70
$$

No presente trabalho, todas as amostras irradiadas nas doses de 2; 5 e $10 \mathrm{kGy}$ produziram produtos específicos da amplificação de A. flavus, sendo possível a observação de bandas de DNA no gel, demonstrando que a probabilidade de quebra das duplas fitas, causada pela ação da irradiação no DNA fúngico, conforme citado, não causou influência na amplificação do DNA do A. flavus, pela técnica qualitativa de PCR. 
As amostras de milho irradiadas com $20 \mathrm{kGy}$ e posteriormente inoculadas com A. flavus demonstraram a presença de bandas intensas de DNA de A. flavus em todas as amostras analisadas (FIG. 22). Também foi possível visualizar as bandas de DNA nas amostras irradiadas com $2 \mathrm{kGy}$, exceto linha 4 onde não há banda formada, por perda da amostra (FIG. 22 - b). Em todas as amostras de milho irradiadas com $5 \mathrm{kGy}$, nota-se a formação de bandas de DNA de A. flavus fortemente definidas, conforme imagem registrada (FIG. 22-c), observado também na amostra irradiada com 10 kGy (FIG.22-d). O presente estudo demonstrou que o uso da PCR para um rápido diagnóstico qualitativo do A. flavus, em amostras de milho contaminado é perfeitamente viável.

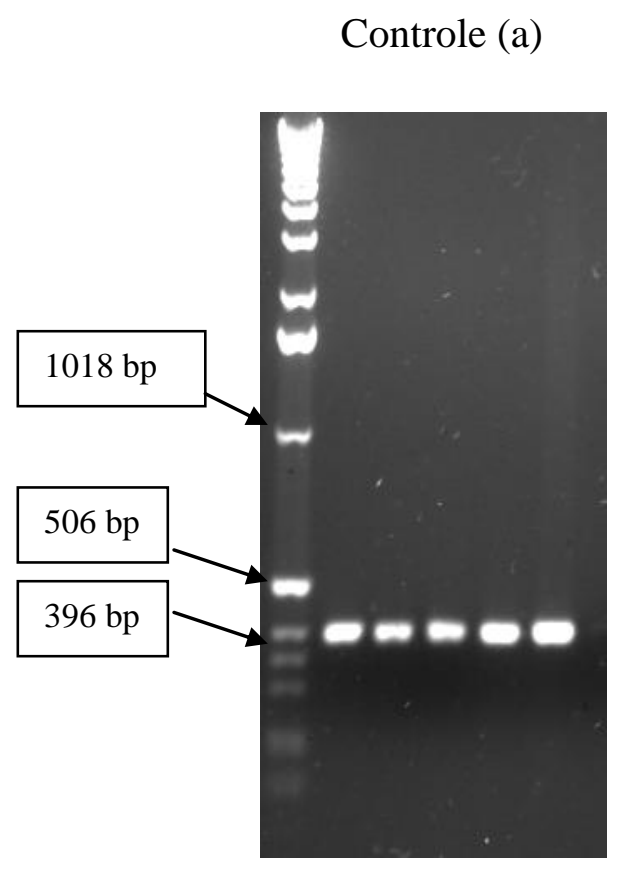

2 kGy (b)

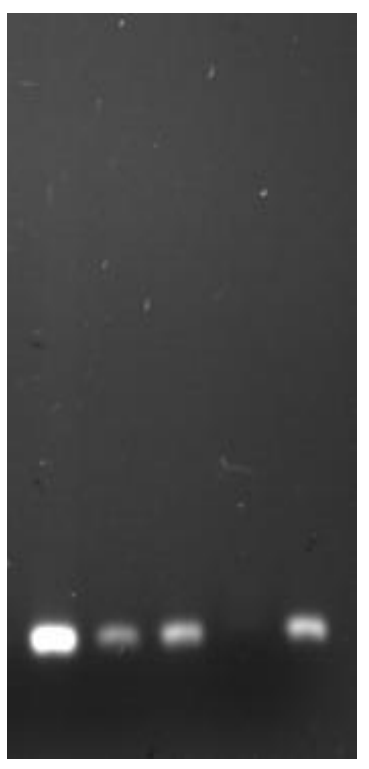

$5 \mathrm{kGy}(\mathrm{c})$

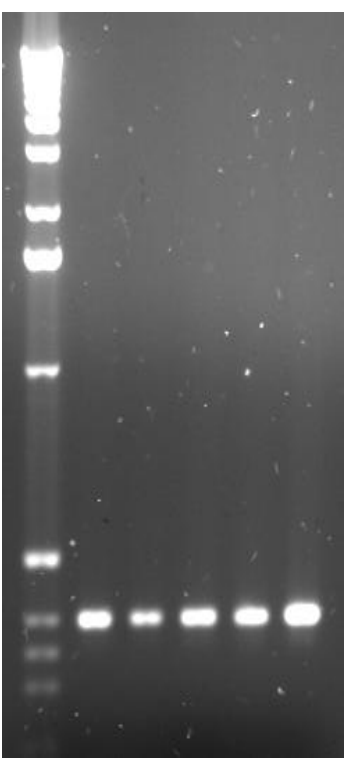

$10 \mathrm{kGy}(\mathrm{d})$

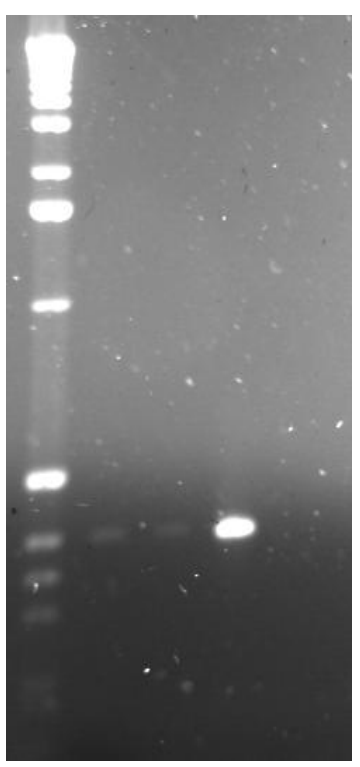

FIGURA 22. Gel de eletroforese de DNA extraído de A. flavus das amostras do Controle e irradiadas com 2, 5 e $10 \mathrm{kGy}$ (PCR). 


\subsection{5 - Teste de viabilidade com corantes fluorescentes DF-BE:}

Quando uma população de microrganismos é irradiada com um dose baixa, somente algumas destas células serão danificadas ou mortas. Com o aumento da dose de radiação, o número de microrganismos sobreviventes diminui exponencialmente (como ocorre com o aumento em tratamentos com calor). Diferentes espécies e diferentes linhagens de uma mesma espécie requerem doses diferentes para atingir o mesmo grau de inativação.

Uma medida de sensibilidade à radiação, comumente usada, é a dose $\mathrm{D}_{10}$, a qual elimina $90 \%$ de uma população. Leveduras se reproduzem principalmente por brotamento ou por bipartição de uma única célula, formando novas células, mas também por formação de esporos. Fungos crescem por expansão de estruturas finas chamadas de hifas e também produzem esporos. Da massa de células de leveduras ou de bolores durante a produção de hifas, é difícil realizar a separação de células individuais e conseqüentemente este é o problema para delinear a curva de sobrevivência e determinar o valor $\mathrm{D}_{10}$ para tais organismos (Diehl, 1995).

Uma curva típica de inativação é demonstrada na FIG. 23. Neste caso, a inclinação da curva indica um valor $\mathrm{D}_{10}$ de $0,55 \mathrm{kGy}$ para a inativação de Salmonella typhimurium em carne moída (Kampelmacher, 1981). 
Sobreviventes $(\%)$

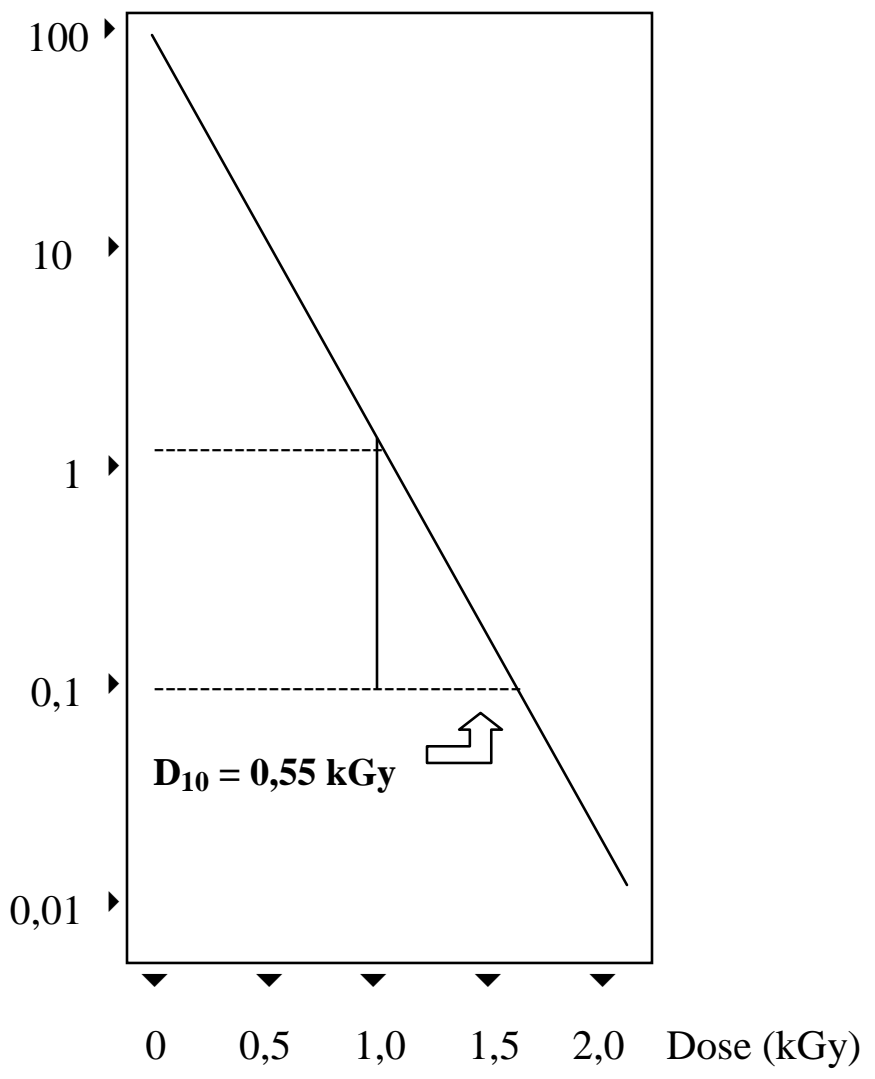

FIGURA 23. Efeitos da irradiação em S. typhimurium em carne moída. (Adaptado de Kampelmacher, 1981).

Para bolores e leveduras, um número de esporos (previamente determinados) são inoculados em meios de cultivo ou em amostras de alimentos, as quais são irradiadas com diferentes doses. As amostras são testadas para a presença ou ausência de sobreviventes após a incubação. O crescimento dos fungos pode ser visualizado em placas de Petri (Diehl, 1995).

Com a evidenciação de que o diacetato de fluoresceína podia ser utilizado como indicador da viabilidade de células de mamíferos, tendo como base a propriedade que possuem as células fúngicas de acumular a fluoresceína (fluocromasia) abriu-se caminho para novas 
possibilidades como a determinação da viabilidade de culturas de fungos, coloração fluorescente de bactérias e de microrganismos do solo (Corrêa et al., 1990).

Observa-se que conforme o aumento das doses, a freqüência de células mortas (coradas em vermelho) aumentou progressivamente. Fato contrário ocorreu em relação às células viáveis (coradas em verde) irradiadas nas três doses do ensaio (TAB. 15). As células viáveis coradas pelo Diacetato de Fluoresceína - DF exibiram três padrões de fluorescência (PF), a saber (FIG. 24):

PF1- Encontrado nas amostras de milho do grupo controle, representado por células intensamente coradas em tonalidade verde brilhante;

PF2- Encontrado nas amostras de milho irradiadas com 2, 5 e $10 \mathrm{kGy}$, representada por células com coloração esverdeada apresentando fraca intensidade fluorescente;

PF3- Encontrado nas doses de 5 e $10 \mathrm{kGy}$, com fluorescência somente na região da parede celular, lembrando formato em anel. A região intracelular, por sua vez, não se apresentava corada. 


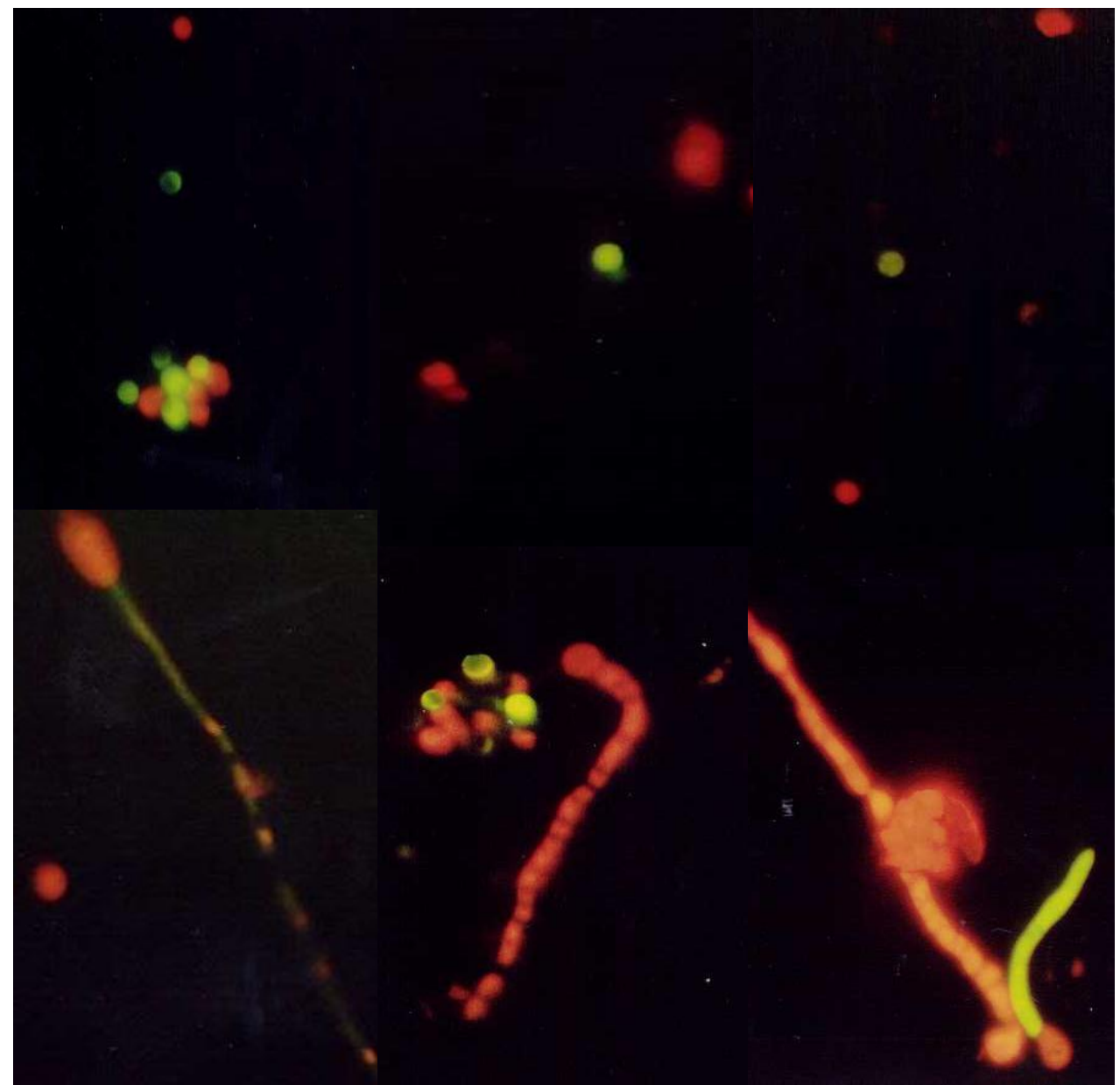

FIGURA 24. Foto de 6 campos observados em microscópio de fluorescência realizadas no Departamento de Micotoxinas - ICB/USP. 
TABELA 16. Freqüência de células vivas e mortas, coradas pelo método fluorescente (DF-BE) das amostras de milho do grupo controle e irradiadas com 2, 5 e $10 \mathrm{kGy}$.

\begin{tabular}{|c|c|c|c|c|c|c|c|}
\hline \multicolumn{2}{|c|}{ Controle } & \multicolumn{2}{|c|}{$2 \mathrm{kGy}$} & \multicolumn{2}{|c|}{$5 \mathrm{kGy}$} & \multicolumn{2}{|c|}{10 kGy } \\
\hline Células & Células & Células & Células & Células & Células & Células & Células \\
\hline Mortas & Vivas & Mortas & Vivas & Mortas & Vivas & Mortas & Vivas \\
\hline$\%$ & $\%$ & $\%$ & $\%$ & $\%$ & $\%$ & $\%$ & $\%$ \\
\hline 14 & 86 & 94 & 6 & 98 & 2 & 96 & 4 \\
\hline 25 & 75 & 94 & 6 & 96 & 4 & 98 & 2 \\
\hline $\mathrm{NC}$ & $\mathrm{NC}$ & 98 & 2 & 95 & 5 & 99 & 1 \\
\hline $\mathrm{NC}$ & $\mathrm{NC}$ & 94 & 6 & 98 & 2 & 99 & 1 \\
\hline$* X=19,5$ & $* X=81,5$ & $X=95$ & $X=5$ & $X=96,8$ & $X=3$ & $X=98$ & $X=2$ \\
\hline (D.P.) 7,8 & & (D.P.) 2,0 & & (D.P.) 1,5 & & (D.P.) 1,4 & \\
\hline I.C. $(95 \%)$ & & I.C. $(95 \%)$ & & I.C. $(95 \%)$ & & I.C. $(95 \%)$ & \\
\hline $19,5 \pm 70,1$ & & $95,0 \pm 3,2$ & & $96,8 \pm 2,4$ & & $98,0 \pm 2,2$ & \\
\hline
\end{tabular}

- Média de 4 repetições

- * Média de 2 repetições

- DF-Diacetato de Fluoresceína

- BE- Brometo de Etídio

- Não Contado

- D.P. = Desvio Padrão

- I.C. = Intervalo de Confiança

A freqüência das amostras irradiadas com 2, 5 e $10 \mathrm{kGy}$, apresentada pelo teste de viabilidade com corantes fluorescentes DF-BE, demonstrou uma ordem crescente de células mortas, à medida que as doses empregadas foram aumentando. Quanto às células viáveis, estas apresentaram intensidade de fluorescência verde PF1 e PF2, nas amostras irradiadas com 2 kGy, sendo a maioria PF2.

As amostras irradiadas com 5 kGy apresentaram raras células PF1 e 50\% PF2 e PF3, respectivamente. Amostras irradiadas com $10 \mathrm{kGy}$ apresentaram predominantemente células PF3, cuja fluorescência era distribuída mais fortemente na região da parede celular, enquanto que a região intracelular apresentava-se fracamente corada, lembrando o formato em anel. 
Segundo Corrêa et al. (1986), as áreas intensamente coradas pelo DF, Padrão PF1, são sítios possuidores de maior atividade hidrolisante, através da acetilesterases. $\mathrm{O}$ padrão $\mathrm{PF} 2$ (fraca intensidade fluorescente) pode ser atribuído à fraca atividade enzimática. Alguns autores sugerem que a fraca intensidade de fluorescência esteja ligado ao envelhecimento celular. Também devemos considerar a capacidade das células de produzir as enzimas proteases e esterases relacionadas ao mecanismo de penetração do DF, ou baixa atividade hidrolisante através das acetilesterases.

Em nosso estudo, o cultivo das amostras de A. flavus em milho, para cada ensaio nas diferentes exposições à radiação gama, foram realizados no mesmo período de tempo (6 dias), juntamente com o controle. Portanto, a menor intensidade da coloração fluorescente verde não está relacionada com o envelhecimento das células, uma vez que a irradiação foi realizada no material fúngico de mesma idade de cultivo. A intensidade fraca na coloração esverdeada de células viáveis nas doses de 2, 5 e 10 kGy (PF2) em relação ao controle (FP1), ocorre devido aos efeitos diretos e indiretos da radiação nas enzimas envolvidas com o mecanismo de penetração do DF. Além disso, a coloração PF3, pode estar relacionada ao fato da radiação interagir com o conteúdo intracelular do esporo, onde há maior concentração de água, preservando a intensidade do corante fluorescente na parede celular. 


\section{7- CONCLUSÕES}

- Baseado no Número de Unidades Formadoras de Colônias (UFC/g), constatou-se que a radiação ionizante, nas doses de 2, 5 e $10 \mathrm{kGy}$, reduziu o crescimento de A. flavus;

- O teste de viabilidade (DF-BE) demonstrou ser eficiente na avaliação dos danos celulares causados pelas diferentes doses de radiação;

- A irradiação se torna mais eficaz se associada às condições de elevada $A a$ do substrato demonstrando que a presença de água tem um importante papel na destruição de aflatoxina por energia gama, uma vez que doses mais baixas foram mais eficazes na inativação de $\mathrm{AFB}_{1} \mathrm{e}$ $\mathrm{AFB}_{2}$, por apresentarem $\mathrm{A} a$ mais elevada, como observado nas amostras irradiadas com a dose de 2 kGy;

- O emprego da radiação gama, nas três diferentes doses, não resultou diferença nos perfis das bandas de DNA de A flavus;

- O uso da PCR é perfeitamente aplicável no diagnóstico qualitativo do A. flavus em amostras de milho contaminado, como alternativa de detecção rápida. 


\section{8- REFERÊNCIAS}

1. ABBAS, H. K.; MIROCHA, C. J.; MERONUCK, R. A. ; POKORNY, J. D. ; GOULD, S. L.; KOMMEDAHL, T. - Mycotoxins and Fusarium species associated with infected ears of corn in Minnesota. Appl. Environ. Microbiol. v. 54, p. 1930-3, 1988.

2. ABD EL-AAL, S. S., \& AZIZ, N. H. Effetcs of gamma radiation on mycotoxin production by toxigenic moulds in local karish cheese. Egyptian Journal of Microbiology, v. 32, p. 151168, 1997.

3. AVADHANI, N. G. \& RUTMAN, R. J. Synthesis in vivo in cultured mammalian cells. Febs Lett., v. 50, p. 303, 1975.

4. ALMEIDA, A . P. Microbiota fúngica e produção de aflatoxinas e fumonisinas, por cepas de Aspergillus flavus Link e Fusarium moliniforme Sheldon, de três híbridos de grãos de milho recém-colhido. 1996. Dissertação (Mestrado) - Instituto de Ciências Biomédicas da Universidade de São Paulo, São Paulo.

5. ALMEIDA, A. P.; FONSECA, H.; FANCELLI, A. L.; DIREITO, G. M.; ORTEGA, E. M.; CORRÊA, B. Mycoflora and Fumonisin Contamination in Brazilian Corn from Sowing to Harvest. J. Agric. Food Chem., v. 50, nº 13, p. 3877-3882, 2002. 
6. AlmEIDA, R. M. A.; GAMBAlE, W.; CORREAA, B.; PAUlA, C. R.; ASEVEDO, I. G. Mycoflora and aflatoxigenic species of Aspergillus spp. isolated from rice. Rev. Microbiol., v. 22, p. 161-163, 1991.

7. ARX, J. A. The genera of fungi sporulating in pure culture. $2^{\mathrm{a}}$ ed. Vaduz, J. Cramer, 1974.

8. ASEVEDO, I. G.; GAMBALE, W.; CORREAA, B.; PAULA, C. R.; SOUZA, V. M.; ALMEIDA, R. M. A . D. Mycoflora and aflatoxigenic species of Aspergillus spp. isolated from stored maize. Ver. Microbiol., v. 25, p. 46-50, 1994.

9. AZIZ, N. H.; MOUSSA, A. A. Influence of gamma-radiation on mycotoxin producing moulds and mycotoxins in fruits. Food Control, v. 13, p. 281-288, 2002.

10. BRASIL. Ministério da Saúde. Decreto-Lei nº 986, de 21 de outubro de 1969. Institui Normas Básicas sobre Alimentos. Publicada no Diário Oficial da União de 21 de outubro de 1969. Alterado pela Medida Provisória n 2.190-34, de 23 de agosto de 2001

11. BRASIL. Ministério da Saúde. Decreto ${ }^{\circ}$ 72. 718, de 29 de agosto de 1973. Estabelece normas gerais sobre irradiação de alimentos. Publicada no Diário Oficial da União de 30 de agosto de 1973 .

12. BRASIL. ANVISA. Resolução RDC n 21, de 26 de janeiro de 2001. Aprova regulamento técnico para irradiação de alimentos. Publicada no Diário Oficial da União de 29 de janeiro de 2001. 
13. BRASIL. ANVISA. Resolução n ${ }^{\circ} 274$, de 15 de outubro de 2002. Aprova o regulamento técnico sobre limites máximos de aflatoxinas admissíveis no leite, no amendoim e no milho. Publicada no Diário Oficial da União de 16 de outubro de 2002.

14. BRASIL. Ministério da Agricultura e do Abastecimento e da Reforma Agrária. Portaria n 183, de 21 de março de 1996. Art. 1. Adotar regulamento Técnico MERCOSUL sobre Limites Máximos de Aflatoxinas admissíveis no leite, amendoim e milho, aprovado pela resolução do Grupo Mercado Comum do Sul n 56/94, de 01 de janeiro de 1995. Publicado no Diário Oficial da União de 25 de março de 1996.

15. BULL, L. T. \& CANTARELLA, H. Cultura do milho: fatores que afetam a produtividade. Piracicaba, Potafos, p. 301, 1993.

16. BUTTLER, W. H. Aflatoxin. In: PURCHASE, I. F. H. (Ed). Mycotoxins. Amsterdan: Elsevier Publishing Company, 1974, p. 1-28.

17. BRYNJOLFSSON, A. Chemiclearance of food irradiation: its scientific basis, In: COMBINATION PROCESSES IN FOOD IRRADIATION, 1981, Vienna. Proceedings... Vienna: IAEA, 1981, p. 367-373.

18. CALICH, V. L. G.; PURCHIO, A.; PAULA, C. P. A . New fluorescent viability test for fungi cells. Mycopathologia, v. 66, p. 175-177, 1978.

19. CASTRO, M. F. P. M. Efeitos da fosfina no crescimento de Aspergillus flavus Link e na produção de aflatoxinas em milho (Zea mays, L.) armazenado com elevados teores de umidade, 2003 - Tese (Doutorado) - UNICAMP, Campinas - SP. 
20. CHRISTIAN, J. H. B. Water activity and the growth of microorganisms. In: LEITCH, J. M.; RHODES, D. N. (Ed.). Recent Advances in Food Science. London Butterworths, 1963, v. 3, p. $248-55$.

21. CHRISTENSEN, C. M.; KAUFMAN, H. H. Grain storage: The role of fungi quality loss. Minneapolis, University Minessota Press, 1969.

22. CONAB (Companhia Nacional de Abastecimento) 2002. Produção brasileira de grãos. Disponível em: 〈http://www.agricultura.com.br > Acesso em: 9 de jun. 2003.

23. CORRÊA, B.; PURCHIO, A.; PAULA, C. R.; GAMBALE, W. Evaluation of a fluorescent method (fluorescein diacetate and ethidium bromide solution) in the study of the viability Cryptococcus neoformans strains. Mycopathologia, v. 96, p. 91-96, 1986.

24. CORRÊA, B.; PURCHIO, A.; PAULA, C. R.; GAMBALE, W.; SHIKANAI-YASUDA, M. A. Método fluorescente (diacetato de fluoresceína e brometo de etídio) para o estudo da viabilidade de Cryptococcus neoformans em líquor. Rev. Inst. Med. Trop. S. Paulo, v.32, n.1, p. 46-50, 1990.

25. CORRÊA, B.; GAMBALE, W.; PAULA, C. R.; PALAZZO, S. Morphogenesis of Sporothrix Scheck "in vivo" and "in vitro" through the method of viability by fluorescence. Appl. Fluoresc. Thenol. v. 3, p.1-9, 1991.

26. COUNCIL FOR AGRICULTURAL SCIENCE AND TECHNOLOGY. Mycotoxins: Risks in Plant, Animal and Human Systems. Task Force Report, Ames, Iowa, USA, n. 139, 2003. 
27. DELINCÉE, H.; VILLAVICENCIO, A. L. C. H.; MANCINI-FILHO, J. Protein quality of irradiated Brazilian beans. Rad. Phys. Chem. v. 52:1-6, p. 43-48, 1998.

28. DELINCÉE, H. Rapid detection of irradiated frozen hamburgers. Rad. Phys. Chem. v. 63: 36, p. 443-446, 2002.

29. DIENER, U. L. \& DAVIS, N. D. Aflatoxin production by isolates of Aspergillus flavus Phytopathology, v. 50, p. 1390-3, 1966.

30. DIENER, U. L. \& DAVIS, N. D. Limiting temperature and relative humidity for aflatoxin production by Aspergillus flavus in stored peanuts. J. Am. Oil. Chem. Soc., v. 47, p. 347-51, 1970.

31. DIEHL, J.F. Food Irradiation: is it an alternative to chemical preservatives? Food Addit. Contam., v. 9, p. 409-416, 1992.

32. DIEHL, J.F.; JOSEPHSON, E. S. Assessment of wholesomeness of irradiated food: a review. Acta Aliment., n. 2, v. 23, p. 195-214, 1994.

33. DIEHL, J.F. Safety of Irradiated Foods- 2. ed. revised and expanded. New York, N. Y.: Marcel Dekker Inc., p. 91 -115, 1995.

34. EDIDIN, M. A rapid quantitative fluorescent assay for cell damage by citotoxic antibodies. J. Immunol., v. 104, p.1303-1306, 1970.

35. FACH, P., GILBERT, M., GRIFFAIS, R., GUILLOUT, J. P., POPOFF, M. R. PCR and gene probe identification of botulinum neurotoxin A-, B-, E-, F-, and producing Clostridium spp. and evaluation in food samples. Appl. Environ. Microbiol. v. 61, p. 389-392, 1995. 
36. FANCELLI, A. L. Tecnologia da Produção. In: Milho - produção, pré-processamento e transformação agroindustrial. São Paulo, Secretaria da Agricultura e Comércio, Ciência e Tecnologia, p. 1-68 (Série 5), 1983.

37. FÄRBER, P.; GEISEN, R.; HOLZAPFEL, W. H. Detection of aflatoxinogenic fungi in figs by a PCR reaction - International Journal of Food Microbiology, v. 36, p. 215-220, 1997.

38. FARKAS, J. Principios de la irradiación de alimentos. In: LA IRRADIACION DE ALIMENTOS EN LATINOAMÉRICA, octubre 24-28,1983, Lima, Perú. Proceedings...Vienna: OIEA, 1985, p. 11-23.

39. FRAZIER, W. C.; WESTHOFF, D. C. Microbiología de los alimentos. 4. Ed. ZARAGOZA: Acribia, 1993.

40. GACHET, E.; MARTIN, G. G.; VIGNEAU, F.; MEYER, G. Detection of genetically modified organisms (GMOs) by PCR: A brief review of methodologies available. Trends in Food Science \& Technology, v. 9, p. 380-388, 1999.

41. GEISEN, R. Multiplex Polymerase Chain Reaction for the detection of potential Aflatoxin and Sterigmatocystin Producing Fungi - System. Appl. Microbiol. v. 19, p. 388-392, 1996.

42. GEISEN, R. PCR Methods for the Detection of Mycotoxin - producing Fungi. In: BRIDGE, P. D.; ARORA, D. K.; REDDY, C. A. ; ELANDER, R. P. (Ed.). Applications of PCR in Mycology. UK, University Press, Cambridge, 2. ed., 2000, p.242-263.

43. GRANT, I. R.; PATTERSON, M. Effect of irradiation and modified atmosphere packaging on the microbiological safety of minced pork stored under temperature abuse conditions. Int. J. Fd. Sci. Technol., v. 26, p. 521-533, 1991. 
44. GRUPO CONSULTIVO INTERNACIONAL SOBRE IRRADIAÇÃO DE ALIMENTOS. Fatos sobre irradiação de alimentos, Vienna, 1999. (Série de fichas descritivas do ICGFI).

45. GUIBAULT, G. C.; KLAMER, N. D. Fluorometric determination of lipase, acylose, alpha e gamma chymotrypsin and inhibitors of these enzymes. Anal. Chem., v. 36, p. 409-412, 1964.

46. HILL, W. E.; KEASLER, S. P. Identification of food-borne pathogens by nuclei acid hybridization, Int. J. Fd. Microbiol., v. 12, p. 67-75, 1991.

47. HILMY, N.; CHOSDU, R. AND MATSUYAMA, A. The effect of humidity after gammairradiation on aflatoxin B1 production of A. flavus in ground nutmeg and peanut. Radiol. Phys. Chem. v 46, n 4-6, p. 705-711, 1995.

48. HIRATA, M. H.; HIRATA, D. C. Técnicas de biologia molecular aplicadas à nutrição. In: V CONGRESSO NACIONAL DA SOCIEDADE BRASILEIRA DE ALIMENTAÇÃO E NUTRIÇÃO. 05 a 08 de Dezembro de 1999, São Paulo. Apostila Teórica do Curso PréCongresso, p. 14-15.

49. HUNTER, J. H. Growth and aflatoxin production in shelled corn by the Aspergillus flavus group as related to relative humidity and temperature. 1969. (Ph.D. Thesis) - Purdue University, Purdue.

50. IAEA, FAO, WHO Facts about Food Irradiation, 1999. Disponível em: <http://www.iaea.org> Acesso em: 12 de ago. 2003.

51. INGRAM, M.; FARKAS, J. Microbiology of foods pasteurized by ionizing radiation. Acta Aliment., v. 6, p. 123-184, 1977). 
52. INTERNATIONAL AGENCY FOR RESEARCH ON CANCER - IARC. Some naturally occurring substances: food items and constituents, heterocyclic aromatic amines and mycotoxins. In: IARC Monographs on the evaluation of carcinogenic risks to humans, IARC, Lyon, 1993, v. 56.

53. JAY, J. M. Microbiologia Moderna de los Alimentos. Zaragoza, Acribia, p. 491, 1978.

54. KAMPELMACHER, E. H. Prospects of eliminating pathogens by the process of food irradiation. In: COMBINATION PROCESSES IN FOOD IRRADIATION, Proceedings... Vienna: IAEA, 1981. p. 265-289.

55. KOZAKIEWCZ, Z.; SMITH, D. Physiology of Aspergillus. In: SMITH. J.E.(Ed). Aspergillus. Plenum Press, New York, 1994. p. 23-37.

56. LACEY, J.; MAGAN, N. Fungi in cereal grains: Their occurrence and water and temperature relationships, In: J. CHELKOWSKI (Ed.). Cereal Grain Mycotoxins, Fungi and Quality in Drying and Storage. Elsevier, Amsterdam, 1991. p. 77-118.

57. LACEY, J.; RAMAKRISHNA, N.; HAMER, A .; MAGAN, N.; MARFLEET, C. Grain fungi. In: ARORA, D. K.; MUKERJI, K. G.; MARTH, E. H. (Eds). Handbook of applied mycology: foods and feeds. New York, Marcel Dekker, 1991.

58. LACEY, J. Water availability and the occurrence of toxigenic fungi and mycotoxins in stored products. In: INTERNATIONAL IUPAC SYMPOSIUM ON MYCOTOXINS AND PHYCOTOXINS, 6., Tokyo, 1988. p. 186-89. 
59. LEITÃO, M. F. F. Microbiologia de alimentos. In: ROITMAN, I.; TRAVASSOS, L. R.; AZEVEDO, J. L. (Eds). Tratado de microbiologia. São Paulo, Manole, 1988. p. 1-81.

60. LEY, F. J.; KENNEDY, T. S.; KAWASHIMA, K.; ROBERTS, D.; HOBBS, B. C. The use of gamma radiation for the elimination of Salmonella from frozen meat. J. Hyg., v.6, p. 293$311,1970$.

61. LOPES, M. A.; FISCHMAN, O.; GAMBALE, W.; CORRÊA, B. Fluorescent method for studying the morphogenesis and viability of dermatophyte cells - Mycopathologia, v. 156, p. 61-66, 2002.

62. MAGOON, K. K.; VISWANATHAN, L.; VENKITASUBRAMANIAN, T. A. The chemistry of aflatoxins. Journal Science Industrial Research. v. 29, p. 8, 1970.

63. MATSUDA, A. H. Aplicação da técnica de irradiação gama para preservação de própolis, 2002 - Dissertação (Mestrado) - Instituto de Pesquisas Energéticas e Nucleares, São Paulo.

64. MAXY, R. B. Irradiation of Food for Public Health Protection. J. Food Prot., v. 45, n. 4, p. 363-366, 1992.

65. MEDZON, E. L.; BRADY, M. L. Direct measurement of acetyl esterase in living protist cells. J. Bacteriol., v. 97, p. 402-415, 1969. 
66. MEIRELLES M. C. A .; CORRÊA, B.; FISCHAMN, O.; GAMBALE, W.; PAULA, C. R.; CHACON-RECHE, N.O.; POZZI, C. R. Mycoflora of the toxic feeds associated with equine leukoencephalomalacia (ELEM) outbreaks in Brazil. Mycopathologia, v. 127, p. 183-8, 1994.

67. MONK, J. D.; BEUCHAT, L. R.; DOYLE, M. P. Irradiation Inactivation of Food-borne Microrganisms. J. Food Prot., Ames, v. 58, n. 2, p. 197-208, 1995.

68. MÜNZNER, R. Some factors affecting the radio sensitivity of molds (in German). Arch. Mikrobiol., v. 64, p. 349-356, 1969.

69. MURANO, E. A. Irradiation of Fresh Meats. Food Technol., p. 52-54, 1995.

70. NASS, M. M. Differential effects of ethidium bromide on mitochondrial and nuclear DNA synthesis in vivo in cultured mammalian cells. Exp. Cell. Res., v. 72, p. 221, 1972.

71. NORTHOLT, M. D.; VAN EGMOND, H. P.; PAULSCH, W. E. Differences between Aspergillus flavus strains in growth and aflatoxin production in relation to water activity and temperature. Journal of Food Protection. Des Moines, v. 40, p. 778-781, 1977.

72. OMS. La irradiación de los alimentos una técnica para conservar y preservar la inocuidad de los alimentos. Genebra, Organización Mundial de la Salud, p. 18-23, 1989.

73. ORSI, R. B.; CORREAA, B.; POZZI, R. C.; SCHAMMASS, E.; NOGUEIRA, J. R.; DIAS, S. M. C.; MALOZZI, M. Mycoflora and occurrence of fumonisins in freshly harvested and stored hybrid maize. J. Stored Products Research, v. 36, p. 75-87, 2000. 
74. PATEL, U. D.; GOVINDARAJAN, P.; DAVE, P. J. Inactivation of aflatoxin $\mathrm{B}_{1}$ by using the synergistic effect of hydrogen peroxide and gamma radiation. Appl. Environ. Microbiol., v. 55, p. $465-467,1989$.

75. PITT, J. I.; HOCKING, A. D.; GLENN, D. R. An improved medium for the detection of Aspergillus flavus and Aspergillus parasiticus. Journal of Applied Bacteriology. v. 54, p. 109-114, 1983.

76. PITT, J. I.; HOCKING, A. D. Fungi and Food Spoilage. Sydney: Academic Press, 1985.

77. PITT, J. I.; HOCKING, A. D. Fungi and Food Spoilage. 2. ed. Gaithersburg: Aspen Pub., Inc., p. 593, 1999.

78. PITT, J. I.; MISCAMBLE, B. F. Water relations of Aspergillus flavus and closely related species. Journal of Food Protection, Des Moines, v. 58, p. 86-90, 1995.

79. POLLARD, E. C. Phenomenology of radiation effects on microorganisms. In: SPRINGERVERLAG (Ed.). Encyclopedia of Medical Radiology. New York, 1966. v. 2(2), p. 1-34.

80. RAPER, K. B.; FENNEL, D. I. In: WILLIAMS \& WILKINS, The genus Aspergillus. Baltimore, 1965.

81. REFAI, M. K.; AZIZ, N. H.; EL-FAR, F. M.; HASSAN, A. A. Detection of ochratoxin produced by $A$. ochraceus in feedstuffs and its control by gamma irradiation. Appl. Radiat. Isto., v. 7, p. 617-621, 1996. 
82. REHANA, F.; BASAPPA, S.C. Detoxification of aflatoxin B1 in maize by different cooking methods. Journal of Food Science and Technology, Mysore, v.27, n.5, p.397-399, 1990.

83. RIDELL, R. W., Permanent stained mycological preparation obtained by slide culture. Mycologia, v. 42, p.265-270, 1950.

84. RODRIGUES, M. A., L. Morfogênese de dermatófitos utilizando método de viabilidade pela fluorescência, 2000. Dissertação (Mestrado) - Instituto de Ciências Biomédicas da Universidade de São Paulo, São Paulo.

85. ROTMAN, B.; PAPERMASTER, B. W. Membrane properties of living mammalian cells as studied hydrolyses of flurogenic esters. Proc. Nat. Acad. Sci, USA, v. 55, P. 134-141, 1966.

86. ROWE, T. F.; TOWNER, K. J. Effect of irradiation on the detection of bacterial DNA in contaminated food samples by DNA hybridization, Lett. Appl. Microbiol., v. 18, p. 171-173, 1994.

87. RUSTOM, I. Y. S. Aflatoxin in food and feed: occurrence, legislation and inactivation by physical methods. Food Chemistry, v. 59, n. 1, p. 57-67, 1997.

88. SAIKI R.; GELFAND D. H.; STOFFEL S.; SCHARF S. J.; HIGUCHI R.; HORN R. T.; MULLIS K. B.; EHRLICH H. A. Primer- directed enzymatic amplification of DNA with a thermostable DNA polymerase. Science, v. 239, p. 487-91, 1988. 
89. SALEH, N. A.; AZIZ, N. H. Incidence of mycotoxins in feedstuffs and effects of gamma irradiation and sodium propionate on aflatoxin production by Aspergillus flavus. Journal of the Egyptian Medical Association, v. 56, p. 281-299, 1996.

90. SATIN, M. The case of food irradiation. International conference of the Agricultural Research Institute, p. 93-110, 1993.

91. SILlIKER, J. H.; ELLIOTT, R. P. Ecologia Microbiana de los Alimentos. Zaragoza, Acribia, v. 1, p. 74-96, 1980.

92. SOARES, L. M. V. AND RODRIGUES - AMAYA, D. B. Survey of aflatoxins, ochratoxin A, zearalenone and sterigmatocystin in some Brazilian foods by using multitoxin thin-layer chromatographic. Journal Association Official. Analytical Chemistry, v. 72, p. 22-26, 1989.

93. SPOLAORE, A. J. G. Irradiação de Alimentos. In: GERMANO, M. I. S.; GERMANO, P. M. L. Higiene e Vigilância Sanitária de Alimentos. 2 ed. São Paulo: Varela , 2003 , v. 1, p. $445-463$.

94. STOLOFF, L. Aflatoxinas: an overview. In: RODRICKS, J. V.; HESSELTINE, C. W.; MEHLMAN, M. A. (Eds.). Mycotoxins in human and animal health. Illinois: Pathotox Opublishers, p. 7-28, 1977.

95. TAKASUGI, M. As improved fluorochromatic cytotoxic test. Transplant. v. 1, p. 148-150, 1971. 
96. TEMCHAROEN, P.; THILLY, W. G. Removal of aflatoxin B1 toxicity but not mutagenicity by 1 megarad gamma radiation of peanut meal. J. Food Safety, v. 4, p. 199-205, 1982.

97. TRENK, H. L. \& HARTMANN, P. A. Effects of moisture content and temperature on aflatoxin production on corn. Appl. Microbiol., v. 19p. 781-4, 1970.

98. TROLLER, J. A; BERNARD, D. T.; SCOTT, N. C. Measurement of water activity. In: SPECK, L. M. (Ed). Compendium of methods for the microbiological examination of foods. New York, American Public Health Association, 1984, p. 124-134.

99. VAN DER ZIJDEN et al. Isolation in crystalline form of a toxin responsible for turkey X disease. Nature, London, v. 195, p. 1062, 1962.

100. VILLAVICENCIO, A. L. C. H. Avaliação dos efeitos da radiação ionizante de ${ }^{60}$ Co em propriedades físicas, químicas e nutricionais dos feijões Phaseolus vulgaris L. e Vigna unguiculata (L.) Walp. 1998. Tese (Doutorado) - Faculdade de Ciências Farmacêuticas da Universidade de São Paulo, São Paulo.

101. VILLAVICENCIO, A. L. C. H.; MANCINI-FILHO, J.; DELINCÉE, H Application of a rapid screening method to detect irradiated meat in Brazil. Rad. Phys. Chem. v. 57: 3-7, p. 295-298, 2000.

102. WILSON, T. M.; NELSON, P. E.; TOUSSOUN, T. A.; MARASAS, W. F. O. The Fusarium research center and proposed diagnostic, reference and research center for Fusarium mycotoxicoses in animals. Proc. Ann. Meet. Am. Assoc. Vet. Lab. Diagn., v. 24, p. 261-76, 1981. 
103. WINSTON, P.W.; BATES, H. D. Saluted solution for the control of humidity in biological research. Ecology, v. 41, p. 232-238, 1960.

104. WORLD HEALTH ORGANIZATION (WHO). Safety and nutritional adequacy of irradiated food. Geneva, p.1-17, 1994.

105. WORLD HEALTH ORGANIZATION (WHO). Mycotoxins (Enviromental Health Criteria, 11). Geneva, p. 21-84, 1979.

106. WYLLIE, T. D.; MOREHOUSE, L. G. Mycotoxic fungi, mycotoxins and mycotoxicoses: mycotoxic fungi and chemistry of mycotoxins. New York: Marcel Dekker, v. 1, p. $537,1977$.

107. YOUSSEF, M. B.; MAHROUS, S. R., \& AZIZ, N. H. Effetcs of gamma radiation on aflatoxin B1 production by Aspergillus flavus in ground beef stored at $5{ }^{\circ} \mathrm{C}$. Journal of Food Safety, v.19, p. 231-239, 1999.

108. ZHOU, G.; WHONG, W. Z.; ONG, T.; CHEN, B. Development of a fungus-specific PCR assay for detecting low-level fungi in an indoor environment. Molecular and Cellular Probes, v. 14, p. 339-348, 2000. 